NBER WORKING PAPER SERIES

\title{
ARE FINANCIAL CRISES BECOMING \\ INCREASINGLY MORE CONTAGIOUS? WHAT \\ IS THE HISTORICAL EVIDENCE ON CONTAGION?
}

\author{
Michael D. Bordo \\ Antu Panini Murshid \\ Working Paper 7900 \\ http://www.nber.org/papers/w7900 \\ NATIONAL BUREAU OF ECONOMIC RESEARCH \\ 1050 Massachusetts Avenue \\ Cambridge, MA 02138 \\ September 2000
}

This paper is based on an earlier paper, "The International Transmission of Financial Crises before World War II: Was there Contagion?" prepared for the ADB/IMF/World Bank conference on "International Financial Contagion," Washington D.C., February, 2000. The authors are indebted to the conference participants for their valuable comments and criticisms. The authors are also indebted to Debajyoti Chakrabarty, Simon Evenett and Peter Montiel for constructive criticisms and comments, as well as Larry Neal and Jong Woo Kim for suggestions about data sources and help obtaining data. Finally we are deeply indebted to Jean Skidmore for patient research assistance and to Patricia Kerster for data work. The views expressed herein are those of the author and not necessarily those of the National Bureau of Economic Research.

(C) 2000 by Michael D. Bordo and Antu Panini Murshid. All rights reserved. Short sections of text, not to exceed two paragraphs, may be quoted without explicit permission provided that full credit, including $(\mathbb{C}$ notice, is given to the source. 
Are Financial Crises Becoming Increasingly More Contagious?

What is the Historical Evidence on Contagion?

Michael D. Bordo and Antu Panini Murshid

NBER Working Paper No. 7900

September 2000

JEL No. G15, N20

\section{$\underline{\text { ABSTRACT }}$}

We examine the evidence of contagion during the pre World War I era and the interwar and contrast our findings with the evidence of contagion from the recent crises in Asia and Latin America.

Using weekly data on bond prices and interest rates, we investigate the extent to which bilateral cross-market correlations rise following the onset of a crisis. After correcting for heteroscedasticity, ala Forbes and Rigobon (1998, 1999), we find little evidence of significant increases in cross-market correlations in either the earlier regimes or in the more recent period.

We use principle components analysis to assess the extent of comovement across all markets as well as within various groups of markets, prior to, and after the onset of a crisis. Countries are grouped into regions, as well as along the lines of advanced and emerging. There is little evidence to suggest that cross-country linkages are tighter in the aftermath of a financial crisis for the recent period. There is, however, some evidence of stronger comovement during periods of instability in earlier regimes.

Michael D. Bordo

Rutgers University

75 Hamilton Street

New Brunswick, NJ 08901-1248

and NBER

bordo@economics.rutgers.edu
Antu P. Murshid

MC 2-386

World Bank Group

1818 H Street, NW

Washington, DC 20433

amurshid@worldbank.org

murshid@economics.rutgers.edu 


\section{Introduction}

The recent series of financial crises in the emerging markets, the Mexican crisis of 199495 and the Asian crisis of 1997-98, closely followed by the devaluations of the Ruble and the Real, have been decried for their virulence and their far-reaching effects beyond their epicenters. Certainly these recent batch of crises have been particularly severe. ${ }^{1}$ Yet, that crises can spread across international borders should not, of its own accord, be surprising; it is merely a reflection of the interdependence of cross-country fortunes in the presence of real and identifiable channels of transmission. Moreover, in the face of macroeconomic imbalances and or structural weaknesses, crises, when they arrive, may simply be a reflection of unsound economic policies or inefficiencies that are fostered in an underdeveloped financial infrastructure. However, as the October 1997 crash on the Hong Kong Exchange demonstrated, good fundamentals alone cannot insulate a country from the effects of financial contagion. ${ }^{2}$ Moreover, the sharp drops on the Brazilian exchange and the eventual devaluation of the Real, following the Russian crisis are difficult to attribute to bad fundamentals or cross-country linkages. ${ }^{3}$

\footnotetext{
${ }^{1}$ Bordo and Eichengreen (1999) assess the severity of the recent financial crises and compare them to crises in the prewar and interwar periods. They find the average drop in output following a crisis, in a sample of ten emerging countries, in the post Bretton Woods period, to be greater than the average drop in output following a crisis in any other period this century.

${ }^{2}$ That Hong Kong was not insulated from the effects of the Asian crisis is a reflection of intra-regional ties, however, unlike many of its neighbors, there was little evidence of the type of corruption and cronyism that have often been associated with the Asian crisis. By contrast the regulatory supervision over the banking system was much stricter. Moreover, government budgets in Hong Kong were conservative.

${ }^{3}$ Whereas we can attribute Hong Kong's woes to regional ties, it is difficult to establish any real linkages that can justify the events that transpired in Brazil as an implication of the crisis in Russia. The heavy losses inflicted on a handful of highly leveraged investors following the Russian crisis, causing some of them to liquidate their positions in Brazil, is one possible channel of transmission. However, it is not clear that this alone could explain why the Brazilian stock market plummeted and eventually forced the government to devalue the currency. In a recent study of the contagion from Russia to Brazil, Baig and Goldfajn (1999), conclude that, "the data does not seem to reflect a compensatory liquidation of assets story by international investors." They conclude that if there was contagion from Russia to Brazil, the most likely source of this contagion was from the offshore Brady market.
} 
These recent crises have led to the view that financial crises can spread across international borders like a contagious disease, unless curtailed by heavy lending by the international financial institutions. Indeed the scope and severity of the recent batch of crises is such, that it has helped crystallize a belief that financial crises, in this new era of globalization, are becoming increasingly more contagious. ${ }^{4}$ Yet from an historical perspective the recent spate of international financial crises is nothing new. In the century and a half preceding World War II there were numerous international financial crises, some of which dwarfed the recent batch in both severity and scope.

In this paper we assess the evidence of contagion in the pre-World War II period and contrast this with our findings for the more recent period. Using weekly data on the price of sovereign debt for nine countries, we focus on two crises from the pre-World War I era - the Baring Crisis in 1890 and the US banking crisis in $1893 .^{5}$ The earlier of these two episodes of instability, had its origins in the financial crisis in Argentina early in 1890. The events there had ramifications for the House of Baring, which triggered a financial crisis in London that eventually fed back to Latin America. We examine the interesting dynamics of that year, by focusing on the first half and the latter half of that year separately. That is we first investigate the extent of contagion stemming from the earlier Argentine crisis, and then examine the contagion following from the troubles of Baring Brothers later that year.

\footnotetext{
${ }^{4}$ The recent series of financial crises has led many to propose the need to establish capital controls. Some have even questioned the longer-term benefits of greater capital account convertibility. Jagdish Bhagwati (1998) for instance has argued that though the benefits of trade liberalization are well established, the case for capital account liberalization is not so clear-cut.

${ }^{5}$ The countries in our sample are Argentina, Belgium, Brazil, Canada, Chile, France, the Netherlands, the UK and the US. Source: The Economist, Weekly Commercial Times, various issues.
} 
For the interwar, we utilize weekly data on bond prices of foreign government bonds that were traded on the NYSE. ${ }^{6}$ Specifically, we focus on the contagion stemming from the crash on the NYSE in 1929, from the UK following the devaluation of sterling in 1931, and from the US following the devaluation of the dollar in 1933. For the recent period we examine the two recent crises to hit Latin America and East Asia. Specifically, we focus on the episodes of volatility following the devaluation of the peso in December, 1994, and the devaluation of baht in July, 1997. For this period, we utilize a weekly data set on short-term interest rates. Our coverage is varied. For the six-month period prior to and after the collapse of the peso, our data spans 15 countries. $^{7}$ This number increases to 23 , for the period spanning the devaluation of the baht. ${ }^{8}$

In section 2 of this paper, we provide an historical account of numerous international financial crises in the nineteenth and twentieth centuries and attempt to identify the possible channels of transmission that could have dictated the spread of these crises. We identify several key channels of transmission, which include linkages through international trade, through lending from the core to the peripheral countries, through arbitrage in short-term securities markets, and through gold flows. With this narrative as background, combined with the aid of a chronology of financial crises (banking and

\footnotetext{
${ }^{6}$ The countries in our sample are: Argentina, Belgium, Brazil, Canada, Chile, Denmark, Finland, France, Germany, Italy, the Netherlands, Sweden, Switzerland, the U.K. and the U.S. Source: Commercial and Financial Chronicles, various issues.

7 The countries in our sample are Australia, Canada, Denmark, France, Germany, Hong Kong, Indonesia, Japan, Malaysia, Portugal, Singapore, Thailand, the U.K. and the U.S. Source: Reuters.

${ }^{8}$ The countries in our sample are Australia, Brazil, Canada, Denmark, Finland, France, Germany, Greece, Hong Kong, Indonesia, Italy, Japan, Malaysia, Mexico, Philippines, Portugal, Singapore, Spain, Sweden, Switzerland, Thailand, the U.K. and the U.S. Source: Reuters.
} 
currency crises) for 21 countries, ${ }^{9}$ both advanced and emerging, in section 3 , we examine the empirical evidence on contagion by examining the behavior of the correlation coefficient in the period surrounding a crisis.

In section 4, we change our perspective from specific episodes of volatility and the contagion stemming from specific countries, and focus instead on the extent of comovement across markets during periods of volatility in general. That is we ask the question, Do financial variables across markets exhibit greater comovement during turbulent periods? Hence we are less interested in whether markets exhibited higher correlations with Thailand following the crisis there, or with Mexico following the peso's collapse, and more concerned with the extent of comovement, across all markets, during periods of volatility. We use principle components analysis to analyze this issue. Our analysis reveals evidence of significant comovement across markets during both periods of turmoil and periods of relative stability. We then take this analysis one step further and examine the evidence of comovements within various groups of countries. Countries are grouped into regional clusters and into advanced and emerging. We use principle components analysis in order to investigate the extent of comovement within these various clusters. For the interwar, we find some evidence of greater comovement following the sterling and dollar devaluations. However, for the recent period, the

\footnotetext{
${ }^{9}$ The chronology of crisis, by Bordo and Eichengreen (1999), was constructed for the following countries: Argentina, Australia, Belgium, Brazil, Canada, Chile, Denmark, Finland, France, Germany, Greece, Italy, Japan, Netherlands, Norway, Portugal, Spain, Sweden, Switzerland, U.K., USA. The countries in our
} 
evidence of tighter cross-market linkages, within various regions of countries or within the set of advanced or the set of emerging countries, is weak. Section 5 concludes.

sample are a subset of these 21 countries for which we were able to obtain weekly data on bond price movements. 


\section{Historical Perspectives on the International Transmission of Financial Crises}

\subsection{The Incidence of International Financial Crises}

The recent series of crises in emerging markets, the Mexican crisis of 1994-95 and the "tequila spillovers" to Latin American and other countries, the Asian crisis of 1997-98 and its "spillovers" to Brazil and Russia, has led to the view that financial crises (both currency and banking crises) tend to spread across countries like a contagious disease unless they are curtailed by vigorous international intervention. From an historical perspective the recent spate of international financial crises is nothing new. In the century and a half preceding World War II there were numerous international financial crises, some of which dwarfed the recent batch in both severity and scope. Below we discuss their incidence and evolution.

The nineteenth century had periodic international financial crises in virtually every decade since 1825. Kindleberger (1986a) Appendix B presents a chronology going back to the seventeenth century. His focus was primarily on showing a common incidence of crises in the core countries of Europe and the U.S. Morgenstern (1959) displays a chronology of stock market panics for European countries and the U.S. from 1880-1939 showing a high degree of cross-country coherence. Thorp's (1926) Business Annals is also a source showing common patterns of banking panics, stock market crashes, and financial stress in 17 countries. Bordo (1986) focused on 4 European countries (U.K., France, Germany, Sweden) and the U.S. and Canada 1870-1939. His chronologies of 
financial crises, banking panics, and stock market crashes highlighted the international coincidence of these events and of several empirical measures of financial stress under the classical gold standard and gold exchange standards. Recently Bordo and Eichengreen (1999) compiled a chronology of banking and currency crises based on historical narratives and a currency crisis index for 21 countries from 1880-1973. (See Figure 1). This chronology is complemented with measures of the economic impact of crises. Again a pattern of recurrent international crises is evident.

From this literature we learn that there were periodic financial crises in a large number of countries over the past century and a half. The key crisis years before World War II were the following: $1825,1837-38,1847,1857,1866,1873,1890-93,1907-1908,1914,1920-$ 21, and 1929-33. In the postwar Bretton Woods regime, although there were currency crises in advanced countries associated with adherence to the adjustable peg exchange rate regime, there were no banking crises and the crises observed had relatively minor economic effects. For the period beginning in 1880 for which we have sufficient data to assess the economic impact of crises, the evidence from Bordo and Eichengreen (1999) suggests that the severity of crises in emerging countries before 1914 may not have been as great as that observed in today's emerging countries and that it is the incidence of twin currency and banking crises today that may account for the different experiences.

\subsection{Patterns of Transmission}


From the historical literature we can discern a number of explanations for the international transmission of crises. These include linkages through international trade, through lending from the core to peripheral countries, through arbitrage in short-term securities markets, stock markets, and commodities markets between advanced countries, and through gold flows and the money supply and psychological factors independent of the other channels.

All of the pre-World War II crises occurred under variants of the gold standard. This has two important implications. First, most countries adhering to gold convertibility after 1880 were tightly linked to each other by the fixed exchange rates of their gold parities and the absence of serious impediments to the flow of goods and capital. This facilitated the transmission of shocks, including financial crises, between countries. Second, these international crises often occurred in periods of deflation when, under the self-regulating operation of the commodity theory of money which in the long-run drives the price level for the gold standard world, an excess demand for monetary gold created an environment of monetary stringency and financial distress (Bordo and Wheelock 1998, Bordo, Duekker, Wheelock 1999).

Within this context the record suggests a number of geographical patterns of crisis transmission. The dominant mechanism was between the advanced countries of Europe, with crises often originating in Great Britain, the center of the international financial system, and from the core to the periphery countries of North America, Latin America, and the rest of the world. However, crises also originated in the periphery and especially 
in the U.S., which spread to Europe and then back to the periphery. Below we document some of the more important episodes.

\subsection{Episodes of International Financial Crises}

1825. The crisis of 1825 is often viewed as the first international financial crisis. The liberation of Latin America in the early 1820s led to a massive inflow of capital from Britain to finance the exploitation of gold and silver mines and of sovereign loans to the newly independent republics. It also led to an export boom. These foreign influences combined with the rapid growth of the new industries of the industrial revolution and liberal monetary expansion in the years after the Napoleonic wars led to a speculative mania on the London Stock Exchange (Gayer, Rostow, and Schwartz 1953, Neal 1998, Bordo 1998). A growing trade imbalance and a drain on the Bank of England's gold reserves led the Bank to raise its discount rate in the summer. A stock market crash in October triggered a banking panic in December, which spread to the continent. The Bank, concerned over its own reserves, did not act quickly enough to allay the panic, which resulted in numerous bankruptcies and a recession. The crisis spread to Latin America as the overseas loans were cut off, a decline in investment and exports reduced tax revenues and led to sovereign debt defaults across the region. It took three decades before the debts were renegotiated and capital flows in Latin American resumed (Marichal 1989). 
1836-38. This crisis was primarily an Anglo-American affair. In 1836, the Bank of England began raising Bank rate in response to an external gold drain caused by poor corn harvests and capital flows to the U.S. to finance a boom in cotton lands. The resultant stock market crash in December 1836, spread to Paris. The effects on the U.S. were dramatic. A reduction in lending to cotton factors in New Orleans sparked a banking panic there that spread through the correspondent banking system to New York. The resultant nationwide panic led to suspension of specie payments in May 1837 that lasted close to a year. The crisis was transmitted through capital market linkages and through specie outflows and their effects on money supply (Temin 1969, Levy-Leboyer 1982, Huffman and Lothian 1984).

1847. This crisis, primarily a European affair, was triggered by the collapse of a speculative boom in railroad shares in London. As in earlier episodes, the British balance of trade turned negative. The Bank reacted to declining gold reserves by raising its discount rate. This ended the boom, caused prices to fall and triggered a major banking panic, which ended only with an announcement that the Chancellor of the Exchequer had signed a letter temporarily suspending the Bank Charter Act, thereby allowing the Bank to issue more notes than would be covered by its gold reserves (Clapham 1945, Dornbusch and Frenkel 1984). According to Kindleberger (1986a), the crisis spread to Germany and Holland in the next year through international banking channels.

1857. This crisis began in the U.S. A railroad stock boom fueled by the recently discovered gold fields in California and British capital, collapsed in August 1857. This 
led to the banking panic of 1857 with widespread bank failures. This crisis spread to England in the fall and, like the 1847 event, was ended in November by a Treasury letter. From England the crisis spread to the continent, with a serious panic in Hamburg in December. According to Kindleberger, the crisis was also felt in South America, South Africa and the Far East.

1873. The crisis of 1873 is viewed as a major international crisis. The run-up to the crisis was a lending boom in Latin America to finance railroads fueled from England and the continent, and a speculative land boom in Germany and Austria fueled by the French gold indemnity paid to Prussia after the Franco-Prussian war. The Austrian, German boom collapsed in a spectacular stock market crash in Vienna in May. Stock markets in Amsterdam and Zurich also crashed. In the U.S. a banking panic in September followed the collapse of a stock market boom in New York with the failure of Jay Cook, a major financier and President of the Union Pacific railroad. According to Kindleberger, the German crisis contributed to the U.S. event as capital flow was cut off despite the fact that the dollar was floating in this period which would have negated the price specie flow channel of transmission. This crisis had serious repercussions in Latin America. The downturn in the European economy ushered in by the crises and the turnaround in world prices from inflation to deflation in this period reduced exports, tax revenues (trade taxes were the principal form of taxation in Latin America), and debt service leading to a new wave of defaults (Marichal 1989). 
1890. The Baring crisis of 1890 triggered an international crisis in England and Latin America that has resonance for today. The crisis culminated a major lending boom from England and the continent in the 1880 s to Argentina and Uruguay to finance railroads and other infrastructure. Many of the loans went to the Argentine provincial banks, that were not financially sound, fueling a monetary expansion and their collapse. The international crisis erupted when the House of Baring (a major investment bank in London that held the unsaleable paper of the Buenos Aires Water Supply and Drainage Company) declared itself to the Bank of England to be insolvent on November 8, 1890. The Bank prevented a panic by arranging a lifeboat operation to re-capitalize Barings with the aid of other major London financial institutions and a temporary rescue loan from the Banque de France and the Russian central bank. The crisis spread back to Latin America with the cessation of British lending to Argentina, Uruguay, and Brazil. According to Kindleberger the 1890 crisis was also linked to a major bank failure in Paris in 1889 and was the foundation for a later series of crises in 1893.

1893. Major crises in the U.S. and Australia in 1893 have been linked to the earlier Baring crisis and to a general downturn in the world price level. The U.S. panic of 1893 is generally associated with the Sherman Silver Purchase Act, a fillip to the Free Silver Movement, which led investors fearing that the issue of silver certificates would force the U.S. off the gold standard, to flee the U.S., hence precipitating a gold outflow and monetary contraction. The proximate cause of the massive banking panic in the summer of 1893 was a stock market collapse and increase in commercial failures that awakened fears about the solvency of commercial banks. 
The Australian crisis was preceded by a land boom, which was in large part financed by domestic bank lending. The immediate cause of the panic was falling export prices, which made it difficult for the pastoral sector to repay its loans. The trigger was the closure of three banks. The crisis was aggravated by a withdrawal of British deposits and loans. Retrenchment by the surviving banks in turn precipitated a long depression (Bordo and Eichengreen 1999).

1907. The 1907 crisis had many of the attributes of the earlier crisis but in terms of its international scope and its virulence it was probably the worst of the gold standard era. According to the chronology in Bordo and Eichengreen, 9 out of their 21 countries were hit by crises. The trigger is said to have been the Bank of England, which began raising its discount rate in 1906 from 3.5 percent to 6 percent to counter a gold drain. This action had the effect of reversing the flow of gold to the U.S. and severely tightening U.S. money market conditions. A stock market crash occurred in early 1907, and economic activity began to decline. In October, depositor runs on trust companies spread to the commercial banks. The money stock declined precipitously, banks suspended cash payments, and the economy entered a sharp recession. According to Kindleberger (1986a) the crisis spread from England via France to Italy, which had been undergoing a speculative boom. The connection was by Paris clearing its decks of London securities and both centers stopped lending to Italy and other peripheral countries (Bonnelli 1982).

1914. The outbreak of World War I precipitated a massive international financial crisis across the world. In the Bordo-Eichengreen (1999) sample of 21 countries, 15 countries 
had currency crises, banking crises, or both. This crisis, unlike the others, did not spread from the core to the periphery but occurred virtually simultaneously in all countries as the belligerents scrambled to liquidate foreign assets. This led to panics in all asset markets and a scramble for high-powered money. Banking panics in the U.S., U.K., and other countries were allayed by timely lender-of-last-resort intervention.

1920-22. The post war deflation and recession, triggered by monetary authorities in the U.S., U.K., and other countries in an attempt to roll back the wartime inflation and post war commodity boom and to restore price levels to their prewar gold standard levels, were associated with both banking and currency crises in a number of countries (Denmark, Italy, Finland, Netherlands, and Norway). However, unlike the crises of the nineteenth century there was no clear pattern of international transmission.

1929-33. The stock market crash on Wall Street in October of 1929 ushered in the greatest worldwide contraction of all time. The collapse in world output from 1929-33 was heralded by a collapse in commodity prices in the emerging countries. The stock market boom in New York by 1928 choked off U.S. capital flows to central Europe and Latin America and precipitated currency crises in a number of countries (Australia, Argentina, Uruguay, and Brazil) early in 1929 (Kindleberger 1986a). The Wall Street crash precipitated by tightening Federal Reserve policy was instantly reflected in stock market crises around the globe. 
The story of the international propagation of the Great Depression is well known (Eichengreen 1992, Kindleberger 1986b, Friedman and Schwartz 1963). The U.S. downturn in 1929 turned into a depression in 1930 and 1931 after the Federal Reserve failed to allay a series of banking panics. The resultant collapse in prices and output worldwide forced sovereign borrowers to cut back on servicing their debts and then to default, precipitating a collapse of foreign lending in 1931. At the same time the U.S. induced depression and deflation precipitated banking and currency crises in central Europe, forcing the U.K. to abandon gold in 1931. Transmission occurred through gold flows, the money supplies, and capital flight. Adherence to gold for most countries acted as "golden fetters" preventing monetary authorities from following expansionary monetary policy (Eichengreen 1992). 


\section{Correlations Analysis}

Recent studies, such as Baig and Goldfajn (1998, 1999), Forbes and Rigobon (1998), have tested for contagion in financial markets by examining the behavior of the correlation across countries, in financial market variables, such as securities prices, interest rates and exchange rates. Whereas high correlations across countries is not in itself evidence of contagion, as this may merely reflect historic cross-country dependence, significant increases in the correlation coefficient are typically interpreted as evidence of contagion. The idea underlying such tests is the view that the strength of cross-country linkages is state dependent. The occurrence of a bad state, in particular a crisis, excites otherwise dormant channels of transmission, radically changing the nature of the linkages between countries, thus amplifying the cross-border impact of a shock, which shows up as an increase in the correlation coefficient.

However, cross-country correlations are highly volatile, whether during turbulent periods or periods of relative tranquility, which makes this type of analysis sensitive to the choice of crisis windows. Moreover, as Forbes and Rigobon $(1998,1999)$ have shown, this volatility is not necessarily a reflection of the changing patterns in cross-country linkages. Rather this type of instability may be the outcome of the heteroscedastic nature of the shocks impacting on the markets. ${ }^{10}$ Specifically, if $x$ and $y$ are two series such that $y_{t}=$

\footnotetext{
${ }^{10}$ Unfortunately the Forbes and Rigobon $(1998,1999)$ result is occasionally misinterpreted. Some have interpreted the result as saying that the sample correlation coefficient is a biased estimator of the population correlation coefficient, when heteroscedasticity is present. As elementary statistics has taught us, this is not true. The sample correlation coefficient is indeed biased, in small samples, but the size of this bias depends not on the stochastic properties of the parent populations, but rather on the sample size, and the true value of the population correlation coefficient. See Fisher (1915), Gayen (1951) and Ruben (1966). The point that Forbes and Rigobon are making is that if two series $x$ and $y$ are linearly related according to the
} 
$\beta x_{t}+u_{t}$, where $u_{t}$ is a disturbance, the correlation between $x$ and $y$ is given by $\rho(\mathrm{x}, \mathrm{y})=\beta \frac{\sigma_{x}}{\sigma_{y}}$, where $\sigma_{x}$, is the variance of $x$ and $\sigma_{y}$, is the variance of $y$. Now to the extent that the ratio of the variances $\frac{\sigma_{x}}{\sigma_{y}}$, is changing the correlation between $x$ and $y$ will also be changing.

In this section, we examine the evidence of increases in correlations following a financial crisis in three periods of our history. Given the frequency of our data, in order to allow sufficient degrees of freedom, we examine the evidence of changes in correlations in sixmonth windows of time. ${ }^{11}$ We present the results of our correlation analysis in two ways: (1) in a set of tables that reports pre-crisis and post-crisis correlations, as well as the increase in correlations in the post-crisis period, where increases in correlations that are significant after adjusting for heteroscedasticity are shaded; (2) in a second set of tables that report the average pre-crisis and post-crisis correlations between the crisis countries and the emerging countries and between the crisis countries and the advanced countries.

\subsection{The Pre World War I Period}

equation $y_{t}=\beta x_{t}+u_{t}$, then an increase in the variance of $x$ can lead to an increase in the correlation between $x$ and $y$, even though the value of $\beta$ has remained unchanged. This point is made by means of a very cute example involving a coin tossing game in two stages, in Forbes and Rigobon (1999). We have made a stand here and directed the reader to Forbes and Rigobon (1999), as well as numerous seminal contributions in the statistics literature governing the distribution of the sample correlation coefficient, before this confusion spreads through the literature in aptly contagious fashion.

${ }^{11}$ Our data for the prewar period covers two non-adjacent years -1890 and 1893 . Since the crises we consider often occurred in the last quarter the post-crisis windows are typically taken to be the last quarter of each year. 
In order to compare correlations in the pre-crisis period with those of the crisis period, it was necessary to have some additional information regarding the timing of crises than could be obtained from an annual chronology such as that reported in Bordo and Eichengreen (1999). In each period of instability we discuss the chain of events that culminated in a financial crisis. Other than providing an explanation of the proximate causes of each crisis, this discussion provides clues as to the timing of the events. Since a crisis, banking or currency, however defined, is never so precise as to present an obvious demarcation of a period of tranquility from a period of crisis, the eventual choice of crisis windows is somewhat subjective. Moreover, since crises often occur sequentially across countries, the contagion stemming from a turbulent period typically cannot be attributed to any single event. These caveats need to be kept in mind when interpreting an analysis based on pre- and post-crisis correlations.

The Baring crisis in 1890 erupted on November 8, 1890, when the House of Baring declared itself to be insolvent to the Bank of England. The crisis had its roots in the lending boom from the UK to Latin America. Though a successful rescue package arranged by the Bank of England limited the fallout from the crisis in London, the effects of the crisis were felt in Latin America for several years. The acute financial crisis and monetary instability in Argentina, which began in March of 1890 continued well into 1894 (Thorp 1926). A revival from this depression did not begin until 1895.

Attracting between 40 and 50 per cent of all British funds invested abroad, Argentina in the 1880s was the single most important destination of British capital (Eichengreen 
1997). Following the earlier episodes of default in the $19^{\text {th }}$ century, Argentina's return to the international capital market reflects a combination of both monetary reforms and low interest rates in London.

The inflows of foreign capital fueled a speculative bubble in real estate prices. The bubble eventually burst at the end of the decade, with real estate prices falling in excess of 50\% (Batchelor 1986). As a result of its speculative activity, the Banco de la Nacion (one of the two national banks of Argentina), found itself unable to make its dividend payments, triggering a run on the whole banking system. By April of that year, the Argentine government found itself unable to make its interest payments. Despite initial attempts to reschedule loans and the negotiation of a 10 million pound loan from London, government finances collapsed.

The crisis spread to London when Baring Brothers declared their insolvency to the Bank of England. A rescue package arranged in secret helped minimize the fall out from the crisis. The effects of the crisis were not solely restricted to Latin America, as countries as far a field as Australia and New Zealand found it difficult to raise external finance.

The origins of the banking crisis in the US in 1893 can be traced to the enactment of the Sherman Silver Purchase Act, which was passed on July 14, 1890. The act which stipulated that the Treasury should step-up the purchase of silver to 4.5 million ounces per month (Friedman and Schwartz, 1963), introduced fears that this purchase of silver would produce an inflation that would force the US of gold. These fears were re-ignited 
when a series of runs on trust companies in New York, including the Knickerbocker Trust Company in October 1893, introduced doubts about the solvency of the banking system. A banking panic ensued.

Table 1, which is divided into three parts, reports the unadjusted pre- and post-crisis correlations along with the increases in correlations in the post-crisis period. An asterix denotes that the increases are significant at $10 \%$, while a double asterix indicates significance at $5 \% .{ }^{12}$ Shaded entries are significant after adjusting for heteroscedasticty. Tables 1 a) and $1 \mathrm{~b}$ ) examine the correlations in crisis and pre-crisis periods during the Baring crisis. Specifically, Table 1 a) focuses on the contagion stemming from the crisis in Argentina, which can be traced to the troubles of the Banco de la Nacion in March. The period of tranquility is thus defined as the six-month window prior to this event. The period of crisis is defined as the six-month window after the start of the crisis in Argentina.

Table $1 \mathrm{~b}$ ) focuses on the contagion following from the insolvency of Baring Brothers. Even though Barings disclosed its financial difficulties in November, the crisis window is defined to start in the first week of October. The reason for this has to do with data constraints. Taking the crisis-period one-month back allows more degrees of freedom with which to estimate post-crisis correlations.

\footnotetext{
${ }^{12}$ The distribution of the sample correlation coefficient is complicated. However, a simple transformation, known as the Fisher $\mathrm{z}$ transformation, brings the distribution close to normality (Fisher 1915). In order to test the null hypothesis that two samples of size $n_{1}$ and $n_{2}$ are from two independent bivariate normal populations with correlation coefficients $\rho_{l}$ and $\rho_{2}$ such that $\rho_{l}=\rho_{2}$, we employ the following test statistic:
} 
Table $1 \mathrm{c}$ ) examines the impact of the October 1893 banking panic in the US. The crisisperiod is defined to start in the first week of October. The period of tranquility is taken to be the six-month window prior to this.

Tables 2 a), 2 b) and 2c) report the average pre-crisis and post-crisis correlations between the crisis affected country and the emerging countries as a group and the advanced countries as a group.

Table 1 a) shows that in the pre-crisis period movements in Argentine bond prices were correlated with movements in bond prices in the Netherlands. Negative correlations are observed with Brazil and Chile. Interestingly, the correlation with the UK is highly negative despite the fact that the UK was the largest supplier of capital to Argentina.

In the post-crisis period, we observe that, with the exception of Canadian bonds, price movements of Argentine Cedula bonds were correlated with those of all other foreign bonds. In particular, we observe a high correlation between the Argentine and Dutch bond markets. High correlations are also seen to exist between Argentina and Chile, as well as with the core European nations and the US. The two sharpest increases in correlations are between Argentina and Chile and Argentina and the UK. However, only the increase in correlations with UK are significant at 5\%, and these increases remain

$U=\left(z_{1}-z_{2}\right) / \sqrt{\left[\left(1 / n_{1}-3\right)+\left(1 / n_{2}-3\right)\right]}$, where $z_{i}=\tanh ^{-1}\left(r_{i}\right)$, where $r_{i}$ is the sample correlation coefficient. 
significant at 5\% even after correcting for heteroscedasticty. There thus seems to be evidence of contagion from Argentina to the UK.

The sharp increase in correlation between the UK and Argentina is consistent with the spread of the crisis to London. Figure 2 plots the price of Argentine and UK bonds over time. In the period prior to the crisis, the two series can be seen to be moving in opposite directions. However, from April onwards, one month after the crisis in Argentina was well under way, the movements in the two series are correlated with each other.

Table 2 a) reports the average correlations between Argentina and the emerging countries in our sample, as well as the advanced countries. The Table suggests that in the pre-crisis period, the correlation between Argentina and the emerging countries was significantly higher than the correlation between Argentina and the advanced countries. In the postcrisis period, correlations with both advanced and emerging countries rise strongly. However, if we exclude the UK from the set of advanced countries, then correlations with the two remaining advanced countries in our sample are seen to decrease in the crisis period.

In Table $1 \mathrm{~b}$ ) we switch our attention to the behavior of cross-market correlations in the period following the announcement of the insolvency of Baring Brothers. Several patterns are apparent. We see that in the pre-crisis period, the UK displays high correlations with all the countries in our sample. In particular, we observe high correlations between the UK and Canada and the UK and the US. These high 
correlations may reflect the importance of trade linkages. In particular, the UK was the second most important export market for Canada. We also observe a high correlation between the UK and Chile. This may reflect Chile's openness and strong reliance on its exports of nitrates to the European nations. Interestingly, the correlation between France and the UK is small.

In the post-crisis period, we observe that with the exception of the Netherlands and Argentina, the correlations between the UK and the other nations in our sample turn sharply negative. Interestingly, the correlation between the UK and the other Latin American countries with the exception of Argentina are negative. The analysis seems to suggest that there may have been contagion from the UK to Argentina in the immediate aftermath of the Baring crisis, even though the increase in correlations between the two nations is not significant. In part, this may have to do with the proximity of the crisis in Argentina and the later crisis in London. Since correlations between the UK and Argentina had already increased following the turbulent events their, we would expect to observe fairly high correlations between the two countries in the pre-Baring crisis period.

There is no evidence of contagion from UK to any other country. In fact, all other correlations decrease in the crisis period. Table 2 b) summarizes this finding. We see that even though pre-crisis correlations between the UK and the advanced as well as the emerging countries are on average positive, in the post-crisis period they are negative. 
Table $1 \mathrm{c}$ ) shows that prior to the crisis, US bond price movements were highly correlated with bond price movements in Belgium, Brazil, Chile, France, the Netherlands, and the UK. On average, we see that correlations between the US and the advanced countries are higher in the pre-crisis period, see Table $2 \mathrm{c}$ ). Interestingly the correlations between the US and Canada are small, even though these countries have traditionally shared strong trade linkages. In the crisis period the correlations between the US and several countries increase, both advanced and emerging, see Table 2 c). In particular, we observe sharp increases in correlations with the UK, France, Brazil and Chile. However, correlations between the US and Canada still remain fairly weak. Though we observe increases in correlations between the US and several countries, none of these increases are significant, even before we adjust for heteroscedasticity. Thus, though there may have been greater comovement between bond markets, we cannot verify this to be statistically significant.

In summary our evidence for the pre World War I period suggests that correlations between countries often increased during periods of turbulence. There is convincing evidence of contagion in the aftermath of the Argentine crisis to both the UK and Chile. However, the evidence of contagion following the Baring crisis on London is not as compelling. Furthermore, the increases in correlations that we observe in the period following the US banking panic in 1893, are not sufficiently strong to withstand statistical scrutiny.

\subsection{The Interwar Period}


As can be seen from Figure 1, the years between 1929-1933 were the most heavily polluted with crises. We focus on the contagion stemming from the onset of three financial crises; the stock market crash of October 1929, the devaluation of sterling on September 21, 1931, and the devaluation of the dollar following the enactment of the Thomas Amendment in May 1933.

The crash of October 1929, though arguably symptomatic of the decline in economic activity that was already underway, is seen by many as the trigger behind the sequence of events that led to the onset of the Great Depression and that helped to pull apart the already fragile international monetary system. On October 21 , margin calls led to heavy selling on the NYSE with the volume of sales exceeding 6 million shares. By October 29, this number had reached 16.4 million, which by today's standard would imply a trading volume in excess of one billion shares. See Malkiel (1996). However, the crash is viewed, there is no doubt that it served only to deepen the slump in the US.

Moreover, the drop in economic activity in the US sparked a precipitous decline in the terms of trade in several primary exporting nations at the periphery, in particular those in Latin America. The negative shock to the terms of trade and the decline in capital imports from New York caused a large outflow of reserves, that led many Latin American countries to either impose exchange controls, or suspend convertibility altogether and issue a moratorium on external debt service (Diaz Alejandro 1983). By the end of 1929, Argentina and Uruguay had already limited gold convertibility (Eichengreen 1996). Between 1930 and 1934, several Latin American countries allowed 
their exchange rates to slip below official parities. The sequential impact of the crash was not restricted to Latin America or the periphery. Australia and New Zealand imposed exchange controls, while Canada sealed off the gold outflow by imposing an embargo on gold exports (Eichengreen 1996).

Despite the shockwave emanating from the wake of the 1929 stock market crash, there were few crises in that year relative to 1931. 1931 was by and far the "year of crises." Altogether 18 countries in our sample of 21 experienced crises. With a banking crisis well underway in the US, in May 1931, Austria suffered a severe banking crisis following the failure of the Kreditanstalt, Austria's largest private bank (Friedman and Schwartz 1963). Within a month the crisis had spread to Germany. In an effort to stem the outflow of gold, the Austrian and German governments were forced to suspend gold convertibility. The instability soon spread to the continent and the UK.

From the onset of the restoration of convertibility at the pre-World War I parity in 1925, the UK was plagued with balance of payments deficits. During the six years that the UK was on the gold standard, these deficits progressively worsened. The global slowdown in demand and increasingly protectionist policies caused a slump in export earnings. Moreover default on debt by several Latin American countries had a deleterious effect on the external balance. By 1931, the crisis-ridden countries of Austria and Germany were forced to impose exchange controls and place a freeze on interest payments. These events served to accelerate the outflow of gold reserves. Moreover, within a backdrop of depressed economic activity and high unemployment, rises in the Bank rate were no 
longer viewed as a credible policy (Eichengreen and Jeanne 1998). On September 21, 1931, Britain was forced to abandon gold convertibility.

The UK's departure from gold set the stage for several countries to break off their ties to gold. Countries with close ties to the UK through trade linkages, as well as those that relied on the London financial markets, followed sterling off gold and pegged their currencies to the pound, thus forming the sterling area (Eichengreen 1996). Other countries that followed the UK off gold, but that did not join the sterling area, included Japan, who competed with the UK in the textiles industry, and Canada, who depreciated her currency to a lesser extent than sterling (Eichengreen 1996). In all some 25 countries followed Britain off gold within a year of the sterling devaluation (Friedman and Schwartz 1963).

The Thomas Amendment to the Agricultural Adjustment Act was enacted into law on May 12, 1933. The Amendment empowered President Roosevelt to reduce the gold content of the dollar by as much as one half of it's original content. Though coming after a period of sustained instability in the US, culminating in the massive banking panic of 1933, the devaluation of the dollar had ramifications on an international scale. The devaluation triggered another round of devaluations at the periphery, in particular in Latin America.

Despite the severity and the international nature of the financial crises from this period, that there was contagion in financial market variables is not necessarily so. The 
sequential dethroning of gold convertibility over the period, is to a large extent a reflection of the underlying weaknesses of the interwar gold exchange standard, which helped to both foster and perpetuate shocks across international borders. The channels of transmission of these shocks have been well documented by Eichengreen (1992). Below we test the evidence of contagion in bond markets. Our data for the interwar is more comprehensive than for the pre-World War I period, providing coverage over a larger number of countries for a larger number of years. We proceed as above by estimating the correlations of weekly changes in bond prices for both crisis and non-crisis periods.

Tables 3 a), b) and c) report the pre- and post-crisis correlations in the periods prior to and after the onset of the three crises, along with the increases in correlations in the postcrisis periods. In particular, Tables 3 a) and 3 c) report the correlations between the US and the other countries in our sample, while Table $3 \mathrm{~b}$ ) reports the correlations between the UK and the other countries.

From Table 3, some patterns are apparent that suggest the importance of linkages through international trade, which are consistent with the predictions of standard gravity equation models as well historical and political ties, see Eichengreen and Irwin (1996). For instance in the period of tranquility prior to the stock market crash of 1929, or the devaluation of the dollar in 1933, we observe positive correlations between the US and Canada that are consistent with historically strong ties between the two nations through international trade. Moreover, we see that prior to the devaluation of sterling in 1931, UK bond prices are highly correlated with several European countries, including the core 
countries, France and Germany. In particular, we observe strong correlations between the UK and Denmark, reflecting linkages between these two countries through international trade.

These patterns are less pronounced in the post-crisis periods. For instance, from Table 3 a), we see that correlations between US and Canadian bond prices decrease sharply following the stock market crash. In the aftermath of the crisis, the US bond market lined up with the European markets. Yet prior to the crash the majority of the European countries displayed negative correlations with the US. In fact the countries that depicted positive correlations in the period of tranquility prior to the stock market crash, typically show negative correlations in the aftermath of the crash. We observe a similar pattern after the devaluation of the dollar. For a large number of countries showing positive correlations with the US in the period of "tranquility," correlations decrease in the aftermath of the crisis. However during the sterling crisis, we observe that correlations between UK bond prices and the majority of the European nations remain positive in the post-crisis period. Indeed the patterns that we observe in the post-crisis period are sharper. We see the UK is strongly correlated with the core European countries - France and Germany - as well as with Canada and the US, reflecting the importance of tradebased channels of transmission.

From Table 3 a), we detect little evidence of contagion from the US bond market, in the period following the stock market crash. Although correlations are seen to increase in the post-crisis period, none of these increases are seen to be statistically significant. Some of 
the increases in correlations may reflect the operation of channels of transmission on both the capital and current accounts. The rise in correlations between the US and Brazil and the US and Chile reflects the transmission of instability to Latin America, which was harshly affected by both the deterioration in the terms of trade and the sharp decline in capital imports from the core, forcing many Latin American countries to impose exchange controls and or suspend debt servicing.

Interestingly correlations between Argentina and the US are seen to decline in the crisis period. This may reflect the early suspension of convertibility in Argentina, which halted the decline in money supply that started a year earlier. Indeed M2 in Argentina and Uruguay, which had both imposed exchange controls, increased between 1929 and 1930 (Diaz Alejandro 1983), while M2 in the US decreased sharply over the same period. By contrast, between 1929 and 1930, M2 fell by 4.5\% in Brazil (Diaz Alejandro 1983), and by $15 \%$ in Chile (Bordo and Schwartz 1996). The suspension of convertibility or the imposition of exchange controls, however, eventually halted the decline in money supply in these economies as well.

Table $3 \mathrm{~b}$ ) suggests sharper increases in correlations following the sterling crisis than that was observed following the crash in 1929. From column 3 of Table 3 b), we observe that 6 of these increases are significant at $10 \%$. However, after correcting for heteroscedasticity, we find that none of these increases are significant. This suggests that a large proportion of the increase in correlations that we observe can be attributed to greater volatility in the UK bond market. 
From Table $3 \mathrm{c}$ ) we observe some evidence of increases in correlations following the devaluation of the dollar. For instance, the correlations between the US and Finland, as well as the US and Greece rise sharply. Indeed these increases are significant at $1 \%$. Moreover, they continue to be significant after we correct for heteroscedasticity. We also observe smaller increases in correlation between the US and Canada as well as the US and Chile. These are, however, not significant. Even though we see that correlations with the US do not increase for many countries, we do observe sharp increases that suggest that there could have been contagion from the US to Finland and from the US to Greece. Interestingly, we observe little evidence of contagion from the US to the Latin American countries, even though the devaluation of the dollar sparked another series of devaluations and crises in these countries.

An interesting finding that emerges from our analysis is that typically the correlations with the four emerging countries in our sample are low during tranquil periods, but are often seen to increase sharply in the aftermath of a crisis. For instance prior to the stock market crash, with the exception of Chile, the correlation between the US and the emerging countries in our sample are either weak or negative. In the aftermath of the crash, correlations with Brazil, Chile and Greece increase. We observe a similar pattern following the sterling and dollar devaluations.

Table 4 summarizes these findings. Typically we observe that the average pre-crisis correlations with emerging countries are lower than the average pre-crisis correlations 
with the advanced countries. Moreover, the average post-crisis correlations with the emerging countries are greater than the average post-crisis correlations with the advanced countries following the stock market crash and the dollar devaluation. In each episode the average increase in correlations with the emerging countries exceeded the average increase in correlations with the advanced countries. Though this evidence is not forceful, it is suggestive. The emerging countries were possibly more exposed to shocks from the center countries.

In summary, we see higher correlations during turbulent periods. However few of these increases can be verified to be statistically significant. Typically when we observe increases in correlations, as we do in the aftermath of sterling crisis, these increases wash out after we correct for heteroscedasticity. There is some evidence that seems to suggest that disturbances often spread from the core to the periphery, with the emerging countries depicting sharper increases in correlations on average. We also observe some evidence of patterns that reflect the importance of trade-based channels of transmission. These patterns are, however, typically more difficult to discern in the aftermath of a crisis.

\subsection{The Recent Period}

Tables 5 a) and 5 b) report the correlations in the periods prior to and after the Mexican and Thai crises, as well as the post-crisis increases in correlations. While Tables 6 a) and $6 \mathrm{~b})$ report the average pre-crisis and post-crisis correlations with advanced and emerging countries as a group, as well as the average increases in correlations. 
From Table 5 a) we can discern patterns in the pre-crisis period, which, as was the case for the interwar, suggest the importance of regional linkages, as well as trade-based channels of transmission. For instance prior to the crisis, Mexico is strongly correlated with Canada and displays positive, though slightly weaker correlations, with the US, which suggests the importance of regional ties. Mexico is also positively correlated with several of the East Asian countries in our sample, in particular, with Hong Kong. After the crisis, we observe that several of these correlations increase. In particular, correlations with Thailand and Portugal increase significantly. The correlation between Mexico and Denmark also increases significantly, however, the two countries are still weakly correlated in the post-crisis period. After correcting for heteroscedasticity, we see that none of the increases in correlations are significant at $5 \%$, though the increase in correlations between Mexico and Denmark is significant at 10\%.

Table 6 a) reveals that on average correlations with advanced countries decreased in the aftermath of the peso's devaluation, suggesting that they were largely insulated from the crisis in Mexico. Correlations with the emerging countries, however, increased sharply, suggesting that if there was contagion, the emerging countries were more likely affected.

Table $5 \mathrm{~b}$ ) reveals clear evidence of regional patterns. We observe that prior to the baht devaluation, Thai interest rates were positively correlated with all the other Asian countries. The correlations with the other emerging countries were either weak or negative. Correlations with the advanced countries were in general negative, see Table 6 
b). In the aftermath of the crisis, the correlations with several countries rise. Moreover, there is still strong evidence of regional ties. Correlations with Hong Kong, Indonesia, Japan, Malaysia, and Singapore are positive in the post-crisis period. Of these, the correlations between Thailand and Indonesia and Thailand and Malaysia increase in the turbulent period following the devaluation. This increase may reflect the onset of the crisis in those countries. However, these increases are very small.

Correlations with the other emerging countries are seen to increase dramatically, see Tables 5 b) and 6 b). Although none of these increases are significant at $5 \%$, the rise in correlations with Brazil and Mexico are significant at 10\%. After correcting for heteroscedasticity, we find that the increase in correlations with Brazil remains significant at $10 \%$.

From Table 6 b) we see that in the post-crisis period, on average, correlations with the advanced countries increase. However, even after this increase, these correlations remain weak. An exception is the correlation between Thailand and the US, which remains significant at $5 \%$ even after correcting for heteroscedasticity.

Looking at Table $6 \mathrm{~b}$ ), we observe that, unlike the interwar, or during the Mexican crisis, the average increase in correlations with the advanced countries following the Asian crisis were substantially higher than the average increase in correlations with the emerging countries. However, even after this increase, post-crisis correlations with the 
advanced countries, on average, are still negative. Whereas post-crisis correlations with the emerging countries, were on average quite high.

In summary, there is some evidence of contagion in the aftermath of the recent Mexican crisis to Denmark, and in the aftermath of the Thai crisis to Brazil. Correlations between the US and Thailand are also seen to increase significantly in the aftermath of the crisis. However, this evidence of contagion is not strong. Though we observe several increases in correlation, these increases may, to a large extent, be attributed to greater volatility in financial markets.

\section{Are Linkages Tighter in General During Turbulent Periods?}

Cross-market correlations, whether during periods of turmoil, or periods of relative tranquility, are highly volatile. An analysis based on a comparison of correlations, in two windows of time, is therefore sensitive to how we demarcate a period of turmoil from a period of relative stability. Moreover, since crises can spread rapidly across international borders, it is easy to muddle the effects of contagion from various crises. Our choice of crisis dates, whether arbitrary, or following from some meaningful scientific methodology, can thus crucially impact on the eventual conclusions that we draw. Moreover, though cross-country correlations can be suggestive, such a methodology cannot account for the complex inter-relationships that exist between countries and cannot disentangle the effects of a shock in one country on another. That we observe strong correlations between two countries, or a significant rise in correlations during 
crises periods, may be by virtue of a complex chain of transmission and feedback effects of which we are largely ignorant. Hence a rise in correlations between two markets suggests but does not necessarily imply transmission from one market to the other. Given these concerns, in this section we move away from the issue of contagion stemming from specific countries and from the analysis of bilateral correlations, and instead we ask the broader question, In general do markets display greater comovement with each other during periods of volatility? Put another way, are turbulent periods more conducive to the propagation of shocks than periods of greater stability? ${ }^{13}$

We use principle components analysis to examine the evidence of stronger comovement across markets during turbulent periods in all three regimes. Principle components analysis, allows us to shed some light on this issue by, in effect, collapsing the dimensionality of the data. Principle components analysis, is a statistical technique that linearly transforms a set of correlated variables into a smaller subset of uncorrelated variables, in a manner that aims to capture most of the variation in the data. For any given $p$ variables, it is possible to extract $p$ principle components, assuming that none of these variables are perfectly correlated with each other. These $p$ principle components are just an orthogonal linear combination of the original variables spanning the same space.

The basic statistics that emerge from principle components analysis are the $p$ variances (latent roots) of the principle components, and the associated $p$ variable weight-vectors

\footnotetext{
${ }^{13}$ Bordo and Murshid (1999) use VAR analysis to examine whether comovement was greater following periods of financial instability during the interwar. They find evidence to suggest that cross-market
} 
(latent vectors) that serve as the basis for the transformation of the original variables. The $i$ th latent root, tells us what fraction of the variation in the original data is explained by the $i$ th principle component, while the sum of the first $i$ latent roots, tells us how much of the variation is explained by the first $i$ principle components.

In order to compare the comovement in tranquil periods with that in turbulent periods, in Figures 3 a), 3 b) and 3 c) we graph, for all three regimes, the cumulative variation in the data that is captured by the first $i$ principle components, for $i=1, \ldots, p$, for both pre-crisis and post-crisis periods. If there is greater comovement during turbulent periods, then the graph of the post-crisis variation should be above the graph of the pre-crisis variation and vice versa. Moreover the wider the gap between the two graphs the greater the difference in the extent of comovement during the pre-crisis and post-crisis periods. However, If the two graphs intersect, it is no longer clear whether there is greater comovement in one period over the other.

From Figure 3 a) we can see that there is some evidence of an increase in the comovement in bond prices across all markets following the Baring crisis, however, there is little evidence of greater comovement following the earlier Argentine crisis. We also see evidence of excess comovements across markets following the US banking panic in 1893.

There is also evidence of tighter cross-market linkages in turbulent periods during the interwar. In particular, bond prices are seen to show considerably more comovement in 
the aftermath of Britain's departure from gold in 1931. By contrast the evidence that bond prices were more strongly correlated following the devaluation of the dollar, is considerably weaker. Moreover, there is no indication of stronger comovement in bond prices in the aftermath of the 1929 stock market crash.

For the recent period, the evidence of greater comovement during crisis periods is much weaker. There is little suggestion that the overall extent of comovement was greater following the Mexican crisis. Moreover, we observe that there was lower comovement across countries in the aftermath of the devaluation of the baht.

The above analysis provides mixed evidence with regard to the overall extent of comovement following a crisis. In particular, though we observe evidence that bond prices were more correlated in the aftermath of a crisis in the pre World War I period and the interwar, this is not the case for the recent period. This is not an altogether surprising finding. During the earlier regimes, countries were tightly linked to each other through the fixed exchange rates of their gold parities, which facilitated the transmission of shocks between countries. This needs to be contrasted to the current managed floating regime based on fiat money, which is arguably less open to macro shocks. ${ }^{14}$

If some countries are relatively insulated from the fallout emanating from a crisis, then we would not necessarily expect to observe stronger cross-market ties across all

\footnotetext{
${ }^{14}$ This of course needs to be qualified by the effects of increasing open capital markets, which offset the insulation properties of floating exchange rates. Also it should be noted that within the rubric of the managed float regime, many of the countries in our sample at various times have pegged their currency to the dollar or other dominant currencies.
} 
countries. However, it may be reasonable to expect to observe greater comovement within various groups or clusters of countries in the post-crisis period.

The analysis in section 3 revealed patterns in cross-country correlations that could serve to provide a means by which to separate countries into various groups, in particular regional ties were often seen to be important. Thus we divide the countries into regional groups and examine the extent of within-group comovement in the pre-crisis and postcrisis periods. Moreover, one of the stylized facts of the analysis in section 3 above has been that average correlations with advanced countries decrease in the post-crisis period, or at least increase to a lesser extent than correlations with emerging countries. This seems to imply that advanced countries may be more insulated from the impacts of international shocks than emerging countries and thus suggests that a division along the lines of emerging and advanced countries may be revealing.

In Figures 4 a) and 4 b) we graph, for the various crises during the interwar and the recent period, ${ }^{15}$ the intra-regional variation in the data that is explained by successively increasing numbers of principle components. Similarly, in Figures 5 a) and 5 b) we graph the variation within the group of advanced and emerging countries.

From both Figure 4 and Figure 5, we see that the evidence of stronger comovement within various groups of countries following the onset of a crisis is mixed. There is some evidence of stronger cross-market linkages following the sterling and dollar devaluations during the interwar. This evidence is weaker for recent period. There is, however, some 
indication of an increase in comovement following the devaluation of the peso within the set of advanced countries as well as within the set of emerging countries.

From Figure 4 a) we observe evidence of a strong increase in the comovement in bond prices between the European countries following the onset of the sterling devaluation. Moreover, Figure 5 a) suggests that the extent of comovement between the set of advanced countries, which includes several European countries in our sample increased sharply in the aftermath of the sterling crisis. There is somewhat weaker evidence of stronger comovment between the Latin and North American countries following the stock market crash of 1929. And there is little suggestion of an increase in intra-regional comovement following the devaluation of the dollar.

For the recent period there is some evidence of stronger linkages following the onset of the Mexican crisis. In particular, we observe evidence of an increase in comovement between the set of advanced countries as well as the set of emerging countries. The evidence of greater comovement within the Latin and North American region is weak. However, this evidence must be interpreted liberally, since this group consists of only three countries, namely the US, Canada and Mexico.

Interestingly there is little indication that cross-country ties were greater within any region other than Europe, following the devaluation of the baht. For all other regions, including the Pacific rim, we observe a decrease in the overall extent of comovement.

\footnotetext{
${ }^{15}$ Since our data for prewar era covers only nine countries, we omit the analysis of this period.
} 
This is interesting, since many of Pacific rim nations were affected by the fall out from the Thai devaluation.

In summary, we find some evidence during the earlier regimes of tighter cross-market linkages across all markets during periods of turmoil, but little evidence of this for the recent crises. There is some evidence of greater market comovements within groups of countries during periods of financial instability in the interwar. This evidence is much weaker for the recent period, though there is a suggestion that cross-market linkages may have strengthened in the period following the peso's devaluation.

\section{Conclusion}

In this essay, we have examined seven particularly severe instances of financial instability, spanning 108 years and three regimes, each significantly distinct from the other. Yet from each episode, several underlying themes have emerged. We find that periods of turbulence are typically characterized by higher cross-market correlations. The volatile nature of financial markets means that correlations between markets are always changing, however, this inherent instability in the correlation coefficient is not necessarily a reflection of continuously changing cross-market linkages. Rather these complex dynamics may be a consequence of the heteroscedastic nature of disturbances impacting upon these markets. After adjusting for heteroscedasticity, we find that very few of the increases in correlations can be verified to be statistically significant, suggesting that the dynamics of the correlation coefficient reflect greater volatility rather 
than instability in cross-market relationships. Nevertheless there is some evidence of isolated cases of contagion between specific countries, during all three regimes that we have examined.

The volatility in the correlation coefficient blurs the underlying relationships between markets. Even so, in each episode we have been able to discern regional patterns in correlations that may suggest the importance of trade-based channels of transmission. Although during periods of financial instability these patterns are occasionally more difficult to discern.

Principle components analysis has revealed that the extent of comovement across markets is often unchanged in the aftermath of a crisis. Given stronger correlations between some countries, this evidence suggests higher variance in cross-market correlations during periods of instability. Dividing countries into various regional groups, or along the lines of advanced and emerging, has, however, suggested some tendency of stronger comovement within various groups of countries, particularly during the interwar. By contrast, the evidence of stronger intra-regional or intra-group variation during periods of instability for the recent period, is far weaker.

In summary, despite some evidence that correlations increase during turbulent periods, and of stronger intra-regional comovement during the interwar, we have not been able to establish a strong case for contagion, especially for the recent period. The increases in correlations that withstand statistical scrutiny are often difficult to justify on the basis of 
traditional channels of transmission. This very small number of significant increases could support the idea of contagion, or they could merely be spurious. From a perspective of weeks rather than days, the evidence on contagion is sporadic, and can only be convincingly identified in a discrete number cases. Yet these are the exceptions to the rule that have commanded our attention. Our evidence suggests that the emphasis on contagion in the recent literature is clearly overblown and hence the case for an international crisis manager or an international lender of last resort to deal with contagion is not transparent. 


\section{$\underline{\text { References }}$}

Baig, Taimur and Ilan Goldfajn (1998), "Financial Market Contagion in the Asian Crisis," IMF Working Paper, WP/98/155.

(1999), "The Russian Default and the Contagion to

Brazil," Prepared for the ADB/IMF/World Bank Conference on "International Financial Contagion," in Washington D.C on February 3-4, 2000.

Batchelor, Roy A (1986), "The Avoidance of Catastrophe: Two

Nineteenth Century Banking Crises," in Forrest Capie and Geoffrey E. Wood (eds.)

Financial Crises and the World Banking System. London: Macmillan, pp41-73.

Bhagwati, Jagdish (1998), "The Capital Myth.” Foreign Affairs 77(3): pp.

$77-92$.

Bonelli, Franco (1982), “The 1907 Financial Crisis in Italy: A Peculiar Case of Lender of Last Resort in Action," in Charles P. Kidleberger and Jean Pierre Laffarugue, (eds.), Financial Crises: Theory History and Policy. New York: Cambridge University Press, pp. 51-65.

Bordo, Michael D., (1986), "Financial Crises, Banking Crises, Stock

Market Crashes and the Money Supply: Some International Evidence, 1870-1933," in

Forest Capie and Geoffrey E. Wood (eds.), Financial Crises and the World Banking System. London : MacMillan, pp. 190-248.

Bordo, Michael D., and Anna J. Schwartz (1996), “The Operation of the Specie Standard: Evidence for Core and Peripheral Countries, 1880-1990," in Jorge Braga de Macedo, Barry Eichengreen and Jamie Reis (eds.) Currency Convertibility: The Gold Standard and Beyond. New York: Routledge, pp. 11-83. 
(1998), “Comment on Larry Neal ‘ The Bank of England's

First Return to Gold and the Stock Market Crash of 1825'," Federal Reserve Bank of St. Louis Review, Vol. 79 (May/June), pp. 77-82.

Bordo, Michael D. and David C. Wheelock (1998), "Price Stability and Financial Stability: the Historical Record," Federal Reserve Bank of St. Louis Review, Vol. 80(5), pp. 41-62.

Bordo, Michael D., Michael Duekker and David C. Wheelock (1999), "Inflation Shocks and Financial Distress: An Historical Analysis." Paper presented at the EHA Meetings, Baltimore, Maryland.

Bordo, Michael D. and Barry Eichengreen (1999), "Is Our Current International Economic Environment Unusually Crisis Prone?" Reserve Bank of Australia Conference on Private Capital Flows. Sydney, Australia.

Bordo, Michael D. and Antu P. Murshid (1999), “The International Transmission of Financial Crises before World War II: Was there Contagion?" Prepared for the ADB/IMF/World Bank Conference on "International Financial Contagion," in Washington D.C on February 3-4, 2000.

Clapham, Sir John (1945), The Bank of England. London: MacMillan.

Diaz Alejandro, Carlos F (1983), "Stories of the 1930's for the 1980's," in Pedro Aspe Armella et al. (eds.), Financial Policies and the World Capital Market: The Problem of the Latin American Countries. Chicago: National Bureau of Economic Research.

Dornbusch, Rudiger and Jacob A. Frenkel (1984), “The Gold standard and the Bank of England in the Crisis of 1847," in Michael D. Bordo and Anna J. Schwartz 
(eds.), A Retrospective of on the Classical Gold Standard, 1821-1931. Chicago: University of Chicago Press, 233-271.

Eichengreen, Barry (1992), Golden Fetters; The Gold Standard and the Great Depression, 1929-1933. New York: Oxford University Press. (1996), Globalizing Capital:A History of the International Monetary System. Princeton: Princeton University Press. (1997), "The Baring Crisis in a Mexican Mirror." Mimeo, University of California, Berkeley.

Eichengreen, Barry and Olivier Jeanne(1998),"Currency Crisis and Unemployment: Sterling in 1931,” NBER Working Paper No. 6563.

Eichengreen, Barry and Douglas Irwin (1996), "The Role of History in Bilateral Trade Flows,” NBER Working Paper No. 5565.

Fisher, Robert A. (1915), "Frequency Distribution of the Values of the Correlation Coefficient in Samples from an Indefinitely Large Population," Biometrika, Vol. 10(3), pp. 507-521.

Forbes, Rigobon (1998), "No Contagion, Only Interdependence: Measuring Stock Market Co-Movements," Mimeograph, Massachusetts Institute of Technology. (1999). "Measuring Contagion: Conceptual and Empirical Issues," Prepared for the ADB/IMF/World Bank conference on "International Financial Contagion," in Washington D.C on February 3-4, 2000.

Friedman, Milton and Anna J. Schwartz (1963), A Monetary History of the United States, 1867-1960. Princeton: Princeton University Press. 
Gayen, A. K. (1951), "The Frequency Distribution of the Product Moment Correlation Coefficient in Random Samples of Any Size Drawn from Normal Universes," Biometrika, Vol. 38(3), pp. 219-247.

Gayer, Arthur D. and Walter W. Rostow and Anna J. Schwartz (1953), The Growth and Fluctuation of the British Economy, 1790-1850. Oxford: Clarendon Press.

Huffman, Walker E. and James R. Lothian (1984), "The Gold Standard and the Transmission of Business Cycles, 1833-1932," in Michael D. Bordo and Anna J. Schwartz (eds.), A Retrospective of on the Classical Gold Standard, 1821-1931. Chicago: University of Chicago Press.

Kindlebereger (1986a), Manias, Panics and Crashes: A History of Financial Crises. Third Edition. New York: John Wiley and Sons.

Kindlebereger (1986b), The World in Depression, 1929-1939. Berkeley: University of California Press.

Levy-Leboyer, Maurice (1982), "Central Banking and Foreign Trade: the Anglo-American Cycle in the 1830s," in Charles P. Kidleberger and Jean Pierre Laffarugue, eds. Financial Crises: Theory History and Policy. New York: Cambridge University Press, pp. 66-110.

Malkiel, Burton G. (1996), A Random Walk Down Wall Street. Sixth Edition. New York: W. W. Norton.

Marichal, Carlos (1989), A Century of Debt Crises in Latin America: From Independence to Depression, 1870-1930. Princeton: Princeton University Press. 
Morgenstern, Oskar (1959), International Financial Transactions and Business Cycles. New York: National Bureau of Economic Research.

Neal, Larry (1990), The Rise of Financial Capitalism: International Capital Markets in the Age of Reason. New York: Cambridge University Press. (1998), The Bank of England's First Return to Gold and the Stock Market Crash of 1825," Federal Reserve Bank of St. Louis Review, Vol. 79 (May/June), pp. 53-76.

Rigobon, Roberto, "On the Measurement of the International Propagation of Shocks,” NBER Working Paper No. W7354.

Ruben, Harold (1966), "Some New results on the Distribution of the Sample Correlation Coefficient," Journal of the Royal Statistical Society, Vol. 28(3), pp. 513-525.

Temin, Peter (1969), The Jacksonian Economy. New York: W. W. Norton.

Thorp, Willard (1926), Business Annals. New York: National Bureau of Economic Research. 
Figure 1.A. Countries Affected by Crises, from a Sample of 21 Countries, 1880-1914

Source: Bordo and Eichengreen (1999)

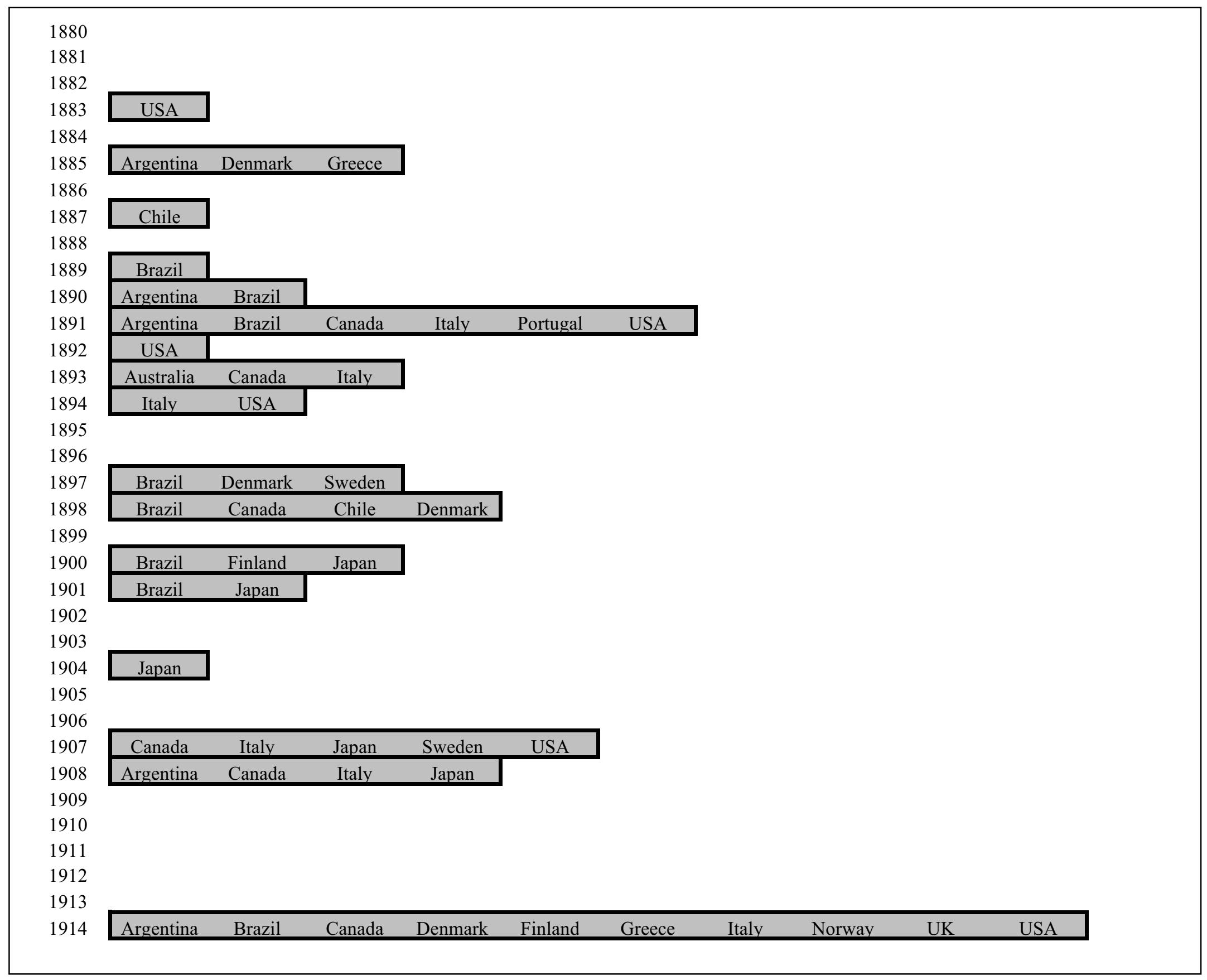


Figure 1. B. Countries Affected by Crises, from a Sample of 21 Countries, 1919-1939

Source: Bordo and Eichengreen (1999)

\begin{tabular}{|c|c|c|c|c|c|c|c|c|c|c|c|c|c|c|c|c|c|c|}
\hline \multicolumn{3}{|l|}{1919} & \multirow[b]{3}{*}{ Finland } & \multirow[b]{3}{*}{ Italy } & \multirow[b]{3}{*}{ Japan } & \multirow[b]{3}{*}{ Neth } & \multirow[b]{3}{*}{ Norway } & & & & & & & & & & & \\
\hline 1920 & Portugal & Spain & & & & & & & & & & & & & & & & \\
\hline 1921 & Canada & Denmark & & & & & & & & & & & & & & & & \\
\hline 1922 & Denmark & Norway & Spain & & & & & & & & & & & & & & & \\
\hline 1923 & Brazil & Canada & France & Neth & Norway & Portugal & Spain & & & & & & & & & & & \\
\hline 1924 & Belgium & & & & & & & & & & & & & & & & & \\
\hline 1925 & Belgium & Chile & & & & & & & & & & & & & & & & \\
\hline 1926 & Belgium & France & & & & & & & & & & & & & & & & \\
\hline 1927 & Japan & & & & & & & & & & & & & & & & & \\
\hline 1928 & & & & & & & & & & & & & & & & & & \\
\hline 1929 & Argentina & Canada & & & & & & & & & & & & & & & & \\
\hline 1930 & Argentina & Brazil & France & Italy & USA & & & & & & & & & & & & & \\
\hline 1931 & Argentina & Belgium & Brazil & Canada & Chile & Denmark & Finland & France & Germany & Greece & Italy & Japan & Norway & Portugal & Spain & Sweden & $\mathrm{UK}$ & USA \\
\hline 1932 & Australia & France & Greece & Japan & Portugal & Sweden & USA & & & & & & & & & & & \\
\hline 1933 & Australia & Switz & USA & & & & & & & & & & & & & & & \\
\hline 1934 & Argentina & Belgium & Germany & & & & & & & & & & & & & & & \\
\hline 1935 & Belgium & Italy & Neth & & & & & & & & & & & & & & & \\
\hline 1936 & France & Italy & Switz & & & & & & & & & & & & & & & \\
\hline 1937 & France & & & & & & & & & & & & & & & & & \\
\hline 1938 & Belgium & & & & & & & & & & & & & & & & & \\
\hline 1939 & Belgium & Finland & Neth & Switz & & & & & & & & & & & & & & \\
\hline
\end{tabular}


Figure 2. Argentine and UK Bond Prices, 1890

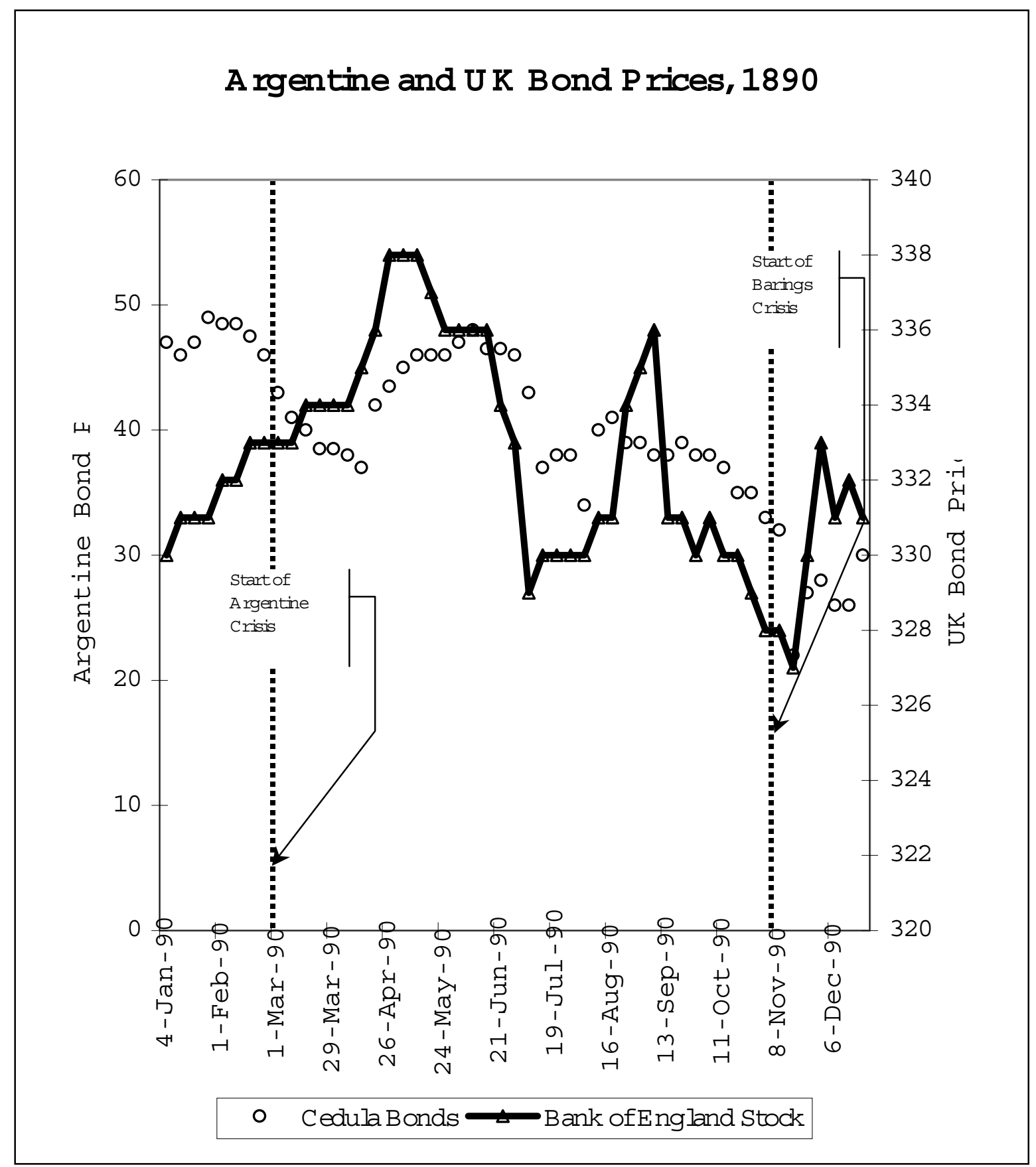


Table 1.A. Correlations With Argentina Prior to and After the Onset of the Argentine Crisis, 1890

\begin{tabular}{|c|c|c|c|}
\hline \multicolumn{4}{|c|}{ Argentine Crisis, 1890} \\
\hline \multicolumn{4}{|c|}{$\begin{array}{c}\text { Pre-crisis period: November 2, } 1890 \text { to February 22, 1890. Post-crisis period:, March 1, } \\
1890 \text { to August 23, } 1890\end{array}$} \\
\hline & $\begin{array}{l}\text { Pre-Crisis } \\
\text { Correlations }\end{array}$ & $\begin{array}{l}\text { Post-Crisis } \\
\text { Correlations }\end{array}$ & $\begin{array}{l}\text { Increase in } \\
\text { Correlations }\end{array}$ \\
\hline Brazil & -0.09 & 0.14 & 0.23 \\
\hline Canada & -0.04 & -0.04 & 0.00 \\
\hline Chile & -0.19 & 0.25 & 0.44 \\
\hline France & 0.01 & 0.19 & 0.18 \\
\hline Dutch & 0.47 & 0.34 & -0.12 \\
\hline$U K$ & -0.52 & 0.16 & $0.67^{* *}$ \\
\hline$U S$ & 0.06 & 0.15 & 0.09 \\
\hline
\end{tabular}

Table 1.B. Correlations With the UK Prior to and After the Onset of the Baring Crisis, 1890

\begin{tabular}{|l|r|r|r|}
\hline \multicolumn{5}{|c|}{ Baring Crisis, November 1890 } \\
\hline Pre-crisis period: April 5, 1890 to September 27, 1890. Post-crisis period:, October 4, 1890 \\
\multicolumn{4}{|c|}{ to December 27, 1890 } \\
\hline & Pre-Crisis Correlations & Post-Crisis Correlations & Increase in Correlations \\
\hline Argentina & 0.14 & 0.52 & 0.38 \\
\hline Brazil & 0.17 & -0.06 & -0.23 \\
\hline Canada & 0.20 & -0.25 & -0.45 \\
\hline Chile & 0.34 & -0.18 & -0.52 \\
\hline France & 0.13 & -0.18 & -0.31 \\
\hline Dutch & 0.18 & 0.15 & -0.03 \\
\hline US & 0.31 & -0.31 & -0.62 \\
\hline
\end{tabular}

Table 1.C. Correlations With the US Prior to and After the Onset of the US Banking Crisis, 1893

\begin{tabular}{|l|r|r|r|}
\hline \multicolumn{5}{|c|}{ US Banking Crisis, 1893 } \\
\hline Pre-crisis period: April 8, 1893 to September 30, 1893. Post-crisis period: October 7, 1893 \\
\multicolumn{4}{|c|}{ to December 30, 1893 } \\
\hline & Pre-Crisis Correlations & Post-Crisis Correlations & Increase in Correlations \\
\hline & -0.04 & -0.24 & -0.20 \\
\hline Argentina & 0.00 & 0.32 & 0.33 \\
\hline Belgium & 0.02 & 0.39 & 0.37 \\
\hline Brazil & 0.13 & 0.11 & -0.02 \\
\hline Canada & 0.10 & 0.41 & 0.30 \\
\hline Chile & 0.08 & 0.46 & 0.38 \\
\hline France & 0.45 & -0.03 & -0.48 \\
\hline Netherlands & 0.04 & 0.51 & $0.47^{*}$ \\
\hline UK & & &
\end{tabular}


Table 2. A. Average Correlations Between Argentina and the Set of Advanced Countries and the Set of Emerging Countries Prior to and After the Onset of the Argentine Crisis, 1890

\begin{tabular}{l|lrr}
\hline & Advanced & & \\
& Countries & Emerging Countries \\
\hline Average pre-crisis advanced & & -0.01 & 0.15 \\
Average Post-Crisis Correlations & & 0.23 & 0.30 \\
Average Increase in Correlations & & 0.24 & 0.19 \\
\hline
\end{tabular}

Table 2. B. Average Correlations Between the UK and the Set of Advanced Countries and the Set of Emerging Countries Prior to and After the Onset of the Baring Crisis, 1890

\begin{tabular}{l|crr}
\hline & Advanced & \\
& Countries & Emerging Countries \\
\hline Average pre-crisis advanced & & 0.16 & 0.23 \\
Average Post-Crisis Correlations & & -0.02 & -0.06 \\
Average Increase in Correlations & & -0.17 & -0.29 \\
\hline
\end{tabular}

Table 2. C. Average Correlations Between the US and the Set of Advanced Countries and the Set of Emerging Countries Prior to and After the Onset of the US Banking Crisis, 1893

\begin{tabular}{l|lrr}
\hline & Advanced & & \\
& Countries & Emerging Countries \\
\hline Average pre-crisis advanced & & 0.14 & 0.06 \\
Average Post-Crisis Correlations & & 0.32 & 0.17 \\
Average Increase in Correlations & & 0.17 & 0.11 \\
\hline
\end{tabular}


Table 3. A. Correlations With the US Prior to and After the Stock Market Crash, 1929

\begin{tabular}{|c|c|c|c|}
\hline \multicolumn{4}{|c|}{ Stock Market Crash, 1929} \\
\hline \multicolumn{4}{|c|}{$\begin{array}{l}\text { Pre-crisis period: April 26, } 1929 \text { to October 18, 1929. Post-crisis period: October 25, } 1929 \text { to April 18, } \\
\text { 1930 }\end{array}$} \\
\hline & Pre-Crisis Correlations & Post-Crisis Correlations & Increase in Correlations \\
\hline Argentina & 0.14 & -0.05 & -0.19 \\
\hline Belgium & -0.20 & -0.06 & 0.14 \\
\hline Brazil & -0.09 & 0.03 & 0.12 \\
\hline Canada & 0.31 & -0.03 & -0.34 \\
\hline Chile & 0.09 & 0.33 & 0.24 \\
\hline Denmark & -0.20 & 0.16 & 0.36 \\
\hline Finland & 0.41 & -0.21 & -0.62 \\
\hline France & -0.09 & -0.12 & -0.03 \\
\hline Germany & -0.12 & -0.07 & 0.05 \\
\hline United Kingdom & 0.02 & -0.19 & -0.21 \\
\hline Greece & -0.30 & 0.01 & 0.31 \\
\hline Italy & -0.05 & 0.05 & 0.10 \\
\hline Japan & 0.10 & 0.09 & -0.01 \\
\hline Netherlands & -0.16 & -0.23 & -0.07 \\
\hline Sweden & 0.09 & 0.09 & 0.00 \\
\hline Switzerland & 0.13 & -0.11 & -0.24 \\
\hline
\end{tabular}

Table 3. B. Correlations With the UK Prior to and After the Sterling Crisis, 1931

\begin{tabular}{|c|c|c|c|}
\hline \multicolumn{4}{|c|}{ Sterling Crisis, 1931} \\
\hline \multicolumn{4}{|c|}{$\begin{array}{c}\text { Pre-crisis period: March 20, } 1931 \text { to September 11, 1931. Post-crisis period: September 18, } 1931 \text { to } \\
1932\end{array}$} \\
\hline & Pre-Crisis Correlations & Post-Crisis Correlations & Increase in Correlations \\
\hline Argentina & 0.03 & -0.02 & -0.05 \\
\hline Belgium & 0.08 & 0.69 & $0.61^{* *}$ \\
\hline Brazil & 0.10 & 0.50 & $0.40^{*}$ \\
\hline Canada & 0.08 & 0.50 & $0.42 *$ \\
\hline Chile & -0.02 & 0.40 & $0.42 *$ \\
\hline Denmark & 0.29 & 0.45 & 0.17 \\
\hline Finland & 0.21 & 0.17 & -0.04 \\
\hline France & 0.11 & 0.63 & $0.52 * *$ \\
\hline Germany & 0.37 & 0.43 & 0.06 \\
\hline Greece & 0.07 & 0.33 & 0.26 \\
\hline Italy & 0.47 & 0.52 & 0.05 \\
\hline Japan & 0.29 & -0.05 & -0.35 \\
\hline Netherlands & -0.02 & 0.13 & 0.15 \\
\hline Sweden & -0.14 & 0.29 & $0.43 *$ \\
\hline Switzerland & 0.06 & 0.29 & 0.23 \\
\hline United States & -0.01 & 0.26 & 0.26 \\
\hline
\end{tabular}


Table 3.C. Correlations With the US Prior to and After the Devaluation of the Dollar, 1933

\begin{tabular}{|l|r|r|r|}
\hline \multicolumn{5}{|c|}{ Dollar Devaluation, 1933 } \\
\hline Pre-crisis period: April 14, 1933 to October 6, 1933. Post-crisis period: October 13, 1933 to April 6, 1934 \\
\hline & Pre-Crisis Correlations & Post-Crisis Correlations & Increase in Correlations \\
\hline Argentina & 0.28 & 0.05 & -0.23 \\
\hline Belgium & 0.36 & -0.05 & -0.40 \\
\hline Brazil & 0.32 & 0.07 & -0.25 \\
\hline Canada & 0.18 & 0.28 & 0.10 \\
\hline Chile & -0.11 & 0.05 & 0.16 \\
\hline Denmark & 0.45 & 0.19 & -0.25 \\
\hline Finland & -0.25 & 0.64 & $0.89 * *$ \\
\hline France & 0.46 & 0.01 & -0.45 \\
\hline Germany & -0.13 & -0.13 & 0.00 \\
\hline Greece & -0.43 & 0.33 & $0.76^{* *}$ \\
\hline Italy & 0.60 & 0.05 & -0.55 \\
\hline Japan & 0.42 & 0.23 & -0.19 \\
\hline Netherlands & 0.44 & 0.02 & -0.42 \\
\hline Sweden & 0.24 & 0.32 & 0.08 \\
\hline Switzerland & -0.07 & -0.20 & -0.13 \\
\hline United Kingdom & 0.20 & -0.01 & -0.20 \\
\hline
\end{tabular}


Table 4 A. Average Correlations Between the US and the Set of Advanced Countries and the Set of Emerging Countries Prior to and After the Stock Market Crash, 1929

\begin{tabular}{lcc|}
\hline \multicolumn{3}{c|}{ October 1929 Stock market crash } \\
\hline & Advanced Countries & Emerging Countries \\
\hline Average Pre-Crisis Correlations & 0.0213 & -0.0396 \\
Average Post-Crisis Correlations & -0.0510 & 0.0789 \\
Average Increase in Correlations & -0.0723 & 0.1185 \\
\hline
\end{tabular}

Table 4 B. Average Correlations Between the UK and the Set of Advanced Countries and the Set of Emerging Countries Prior to and After the Devaluation of Sterling, 1931

\begin{tabular}{ccc|}
\hline \multicolumn{3}{c|}{ Sterling Devaluation, 1931 } \\
\hline & Advanced Countries & Emerging Countries \\
\hline Average Pre-Crisis Correlations & 0.1505 & 0.0467 \\
Average Post-Crisis Correlations & 0.3604 & 0.3028 \\
Average Increase in Correlations & 0.2099 & 0.2561 \\
\hline
\end{tabular}

Table 4 C. Average Correlations Between the US and the Set of Advanced Countries and the Set of Emerging Countries Prior to and After the Devaluation of the Dollar, 1933

\begin{tabular}{lcc|}
\hline & Dollar Devaluation, 1933 & \\
\hline & Advanced Countries & Emerging Countries \\
\hline Average Pre-Crisis Correlations & 0.2409 & 0.0145 \\
Average Post-Crisis Correlations & 0.1135 & 0.1277 \\
Average Increase in Correlations & -0.1275 & 0.1132 \\
\hline
\end{tabular}


Table 5 A. Correlations With Mexico Prior to and After the Devaluation of the Peso, 1994

\begin{tabular}{|l|l|l|l|}
\hline \multicolumn{5}{|c|}{ Peso Crisis, December 19, 1994} \\
\hline & Pre-Crisis Correlations & Post-Crisis Correlations & Increases in Correlations \\
\hline Australia & 0.39 & 0.08 & -0.31 \\
\hline Canada & 0.41 & 0.32 & -0.08 \\
\hline Denmark & -0.33 & 0.08 & $0.41^{*}$ \\
\hline France & -0.16 & 0.21 & 0.37 \\
\hline Germany & -0.13 & -0.11 & 0.02 \\
\hline Hong Kong & 0.20 & 0.39 & 0.19 \\
\hline Indonesia & -0.23 & 0.09 & 0.32 \\
\hline Japan & 0.16 & -0.07 & -0.23 \\
\hline Malaysia & 0.13 & 0.12 & -0.01 \\
\hline Portugal & 0.07 & 0.61 & $0.54^{* *}$ \\
\hline Singapore & -0.30 & -0.21 & 0.09 \\
\hline Thailand & -0.05 & 0.50 & $0.55^{* *}$ \\
\hline UK & -0.19 & -0.05 & 0.14 \\
\hline USA & 0.17 & -0.22 & -0.38 \\
\hline
\end{tabular}

Table 5 B. Correlations With Thailand Prior to and After the Devaluation of the Baht, 1997

\begin{tabular}{|l|l|l|l|}
\hline \multicolumn{5}{|c|}{ Thai Crisis, July 2nd, 1997 } \\
\hline & Pre-Crisis Correlations & Post-Crisis Correlations & $\begin{array}{l}\text { Increases in } \\
\text { Correlations }\end{array}$ \\
\hline Australia & -0.22 & -0.09 & 0.13 \\
\hline Brazil & -0.24 & 0.17 & $0.41^{*}$ \\
\hline Canada & -0.38 & -0.07 & 0.31 \\
\hline Denmark & -0.34 & -0.06 & 0.28 \\
\hline Finland & -0.05 & -0.07 & -0.03 \\
\hline France & -0.46 & -0.18 & 0.28 \\
\hline Germany & -0.05 & -0.07 & -0.03 \\
\hline Greece & -0.05 & 0.18 & 0.22 \\
\hline Hong Kong & 0.38 & 0.12 & -0.26 \\
\hline Indonesia & 0.15 & 0.20 & 0.06 \\
\hline Italy & -0.10 & 0.20 & 0.30 \\
\hline Japan & -0.17 & 0.11 & 0.28 \\
\hline Malaysia & 0.44 & 0.47 & 0.03 \\
\hline Mexico & -0.10 & 0.29 & $0.39^{*}$ \\
\hline Philippines & 0.11 & -0.04 & -0.15 \\
\hline Portugal & 0.04 & -0.05 & -0.08 \\
\hline Singapore & 0.24 & 0.09 & -0.15 \\
\hline Spain & -0.11 & -0.08 & 0.04 \\
\hline Sweden & -0.12 & -0.03 & 0.09 \\
\hline Switzerland & 0.01 & -0.16 & -0.17 \\
\hline UK & -0.05 & 0.01 & 0.06 \\
\hline USA & -0.39 & 0.13 & $0.52^{* *}$ \\
\hline
\end{tabular}


Table 6 A. Average Correlations Between Mexico and the Set of Advanced Countries and the Set of Emerging Countries Prior to and After the Devaluation of the Peso, 1994

\begin{tabular}{ccc|}
\hline \multicolumn{3}{c|}{ Peso Crisis, December 19, 1994 } \\
\hline \multicolumn{3}{c|}{ Advanced Countries } \\
\hline $\begin{array}{c}\text { Average Pre-Crisis } \\
\text { Correlations } \\
\begin{array}{c}\text { Average Post-Crisis } \\
\text { Correlations } \\
\text { Average Increase in } \\
\text { Correlations }\end{array}\end{array}$ & 0.0380 & Emerging Countries \\
\hline
\end{tabular}

Table 6 B. Average Correlations Between Thailand and the Set of Advanced Countries and the Set of Emerging Countries Prior to and After the Devaluation of the Baht, 1997

Thai Crisis, July 2nd, 1997

\begin{tabular}{c|cc}
\hline & Advanced Countries & Emerging Countries \\
\hline $\begin{array}{c}\text { Average Pre-Crisis Correlations } \\
\text { Average Post-Crisis } \\
\text { Correlations }\end{array}$ & -0.1926 & 0.0856 \\
$\begin{array}{c}\text { Average Increase in } \\
\text { Correlations }\end{array}$ & -0.0250 & 0.1353 \\
\hline
\end{tabular}



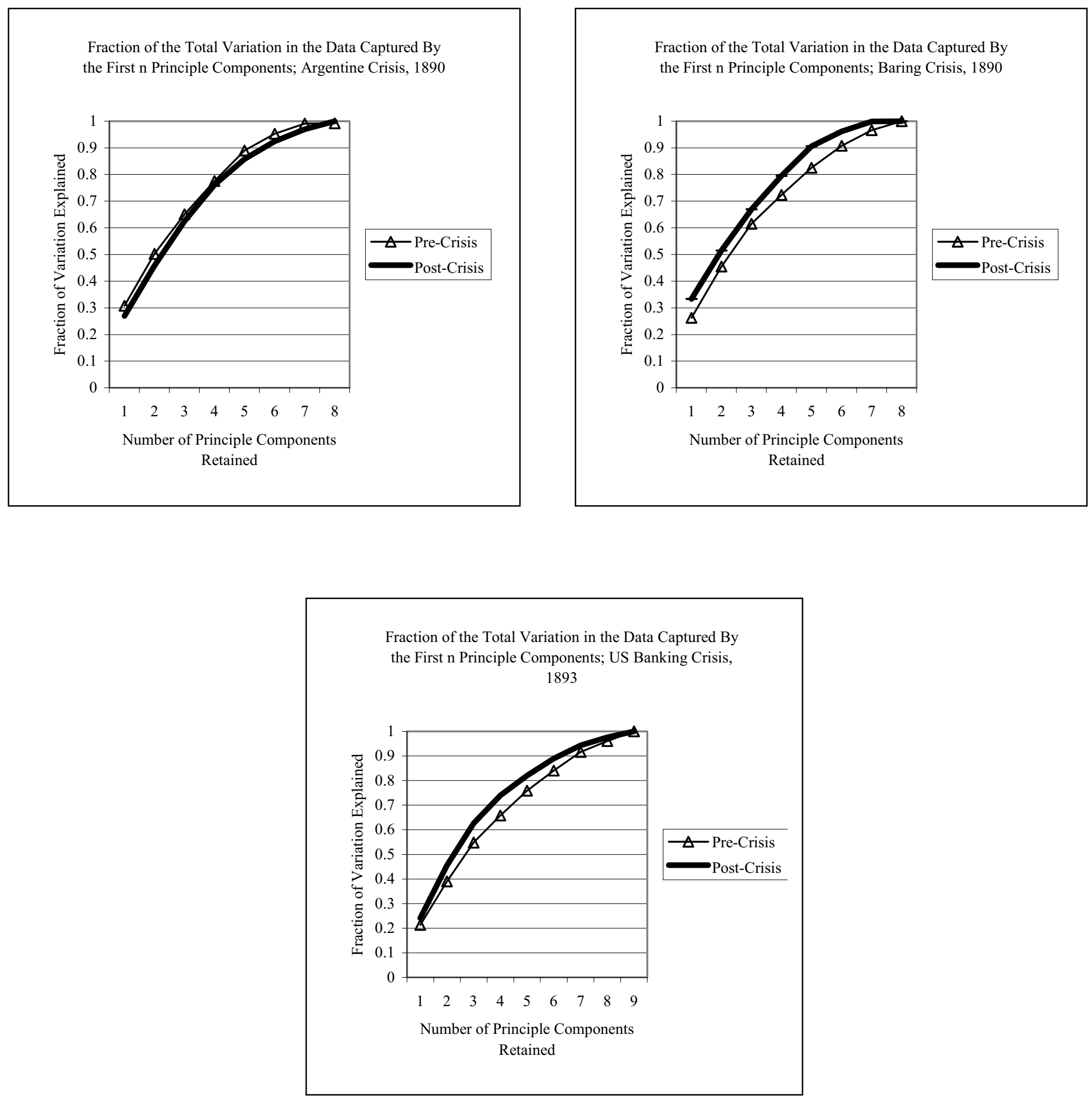
Figure 3. B. Pre-Crisis and Post-Crisis Comovement in Bond Prices Across All Markets; Interwar

Fraction of the Total Variation in the Data Captured By the First $n$ Principle Components; Stock Market Crash, 1929

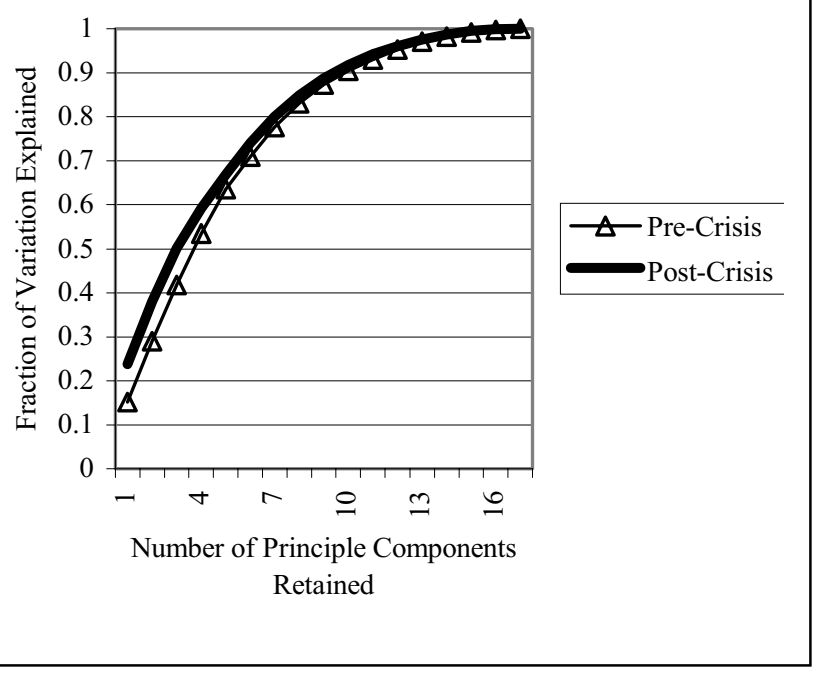

Fraction of the Total Variation in the Data Captured By the First $n$ Principle Components; Sterling Devaluation, 1931

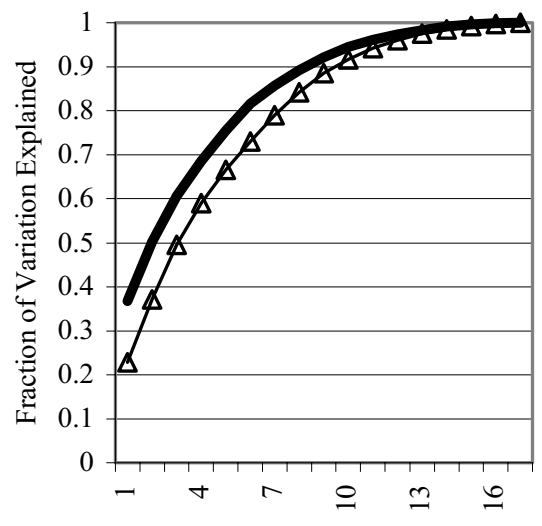

Number of Principle Components Retained $\triangle$ Pre-Crisis

Post-Crisis

Fraction of the Total Variation in the Data Captured By the First n Principle Components; Dollar Devaluation, 1933

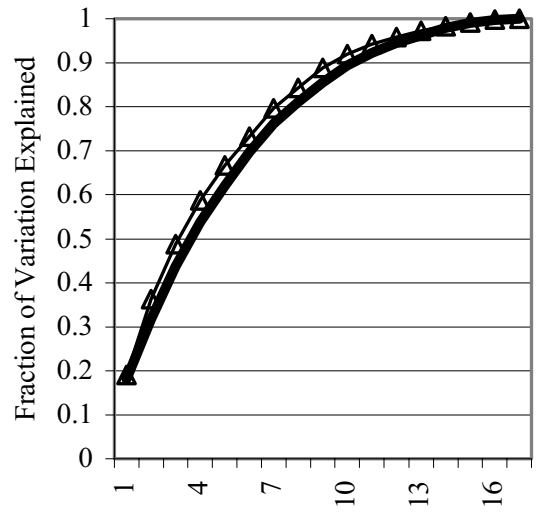

$\triangle$ Pre-Crisis

Post-Crisis

Number of Principle Components

Retained 

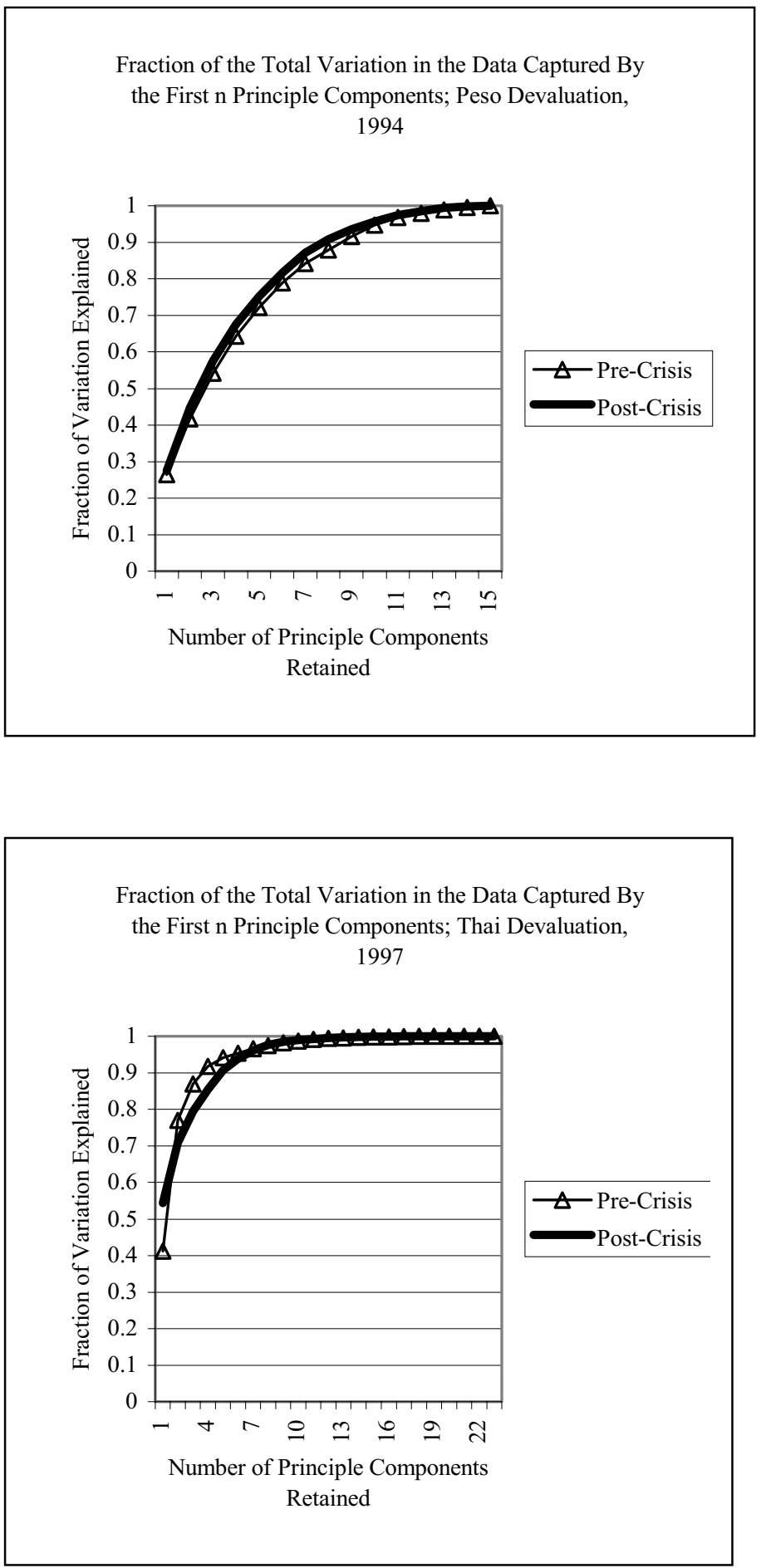
Fraction of the Total Variation in the Data Captured By the First $n$ Principle Components; Stock Market Crash 1929

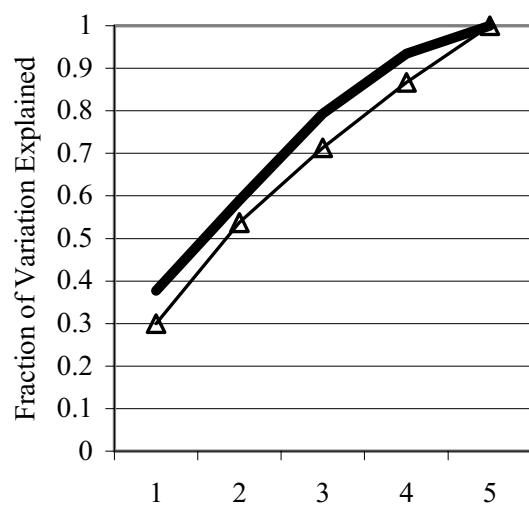

Number of Principle Components Retained

\section{$\triangle$ Pre-Crisis}

\section{Latin and North America}

Fraction of the Total Variation in the Data Captured By the First $\mathrm{n}$ Principle Components; Sterling Devaluation, 1931

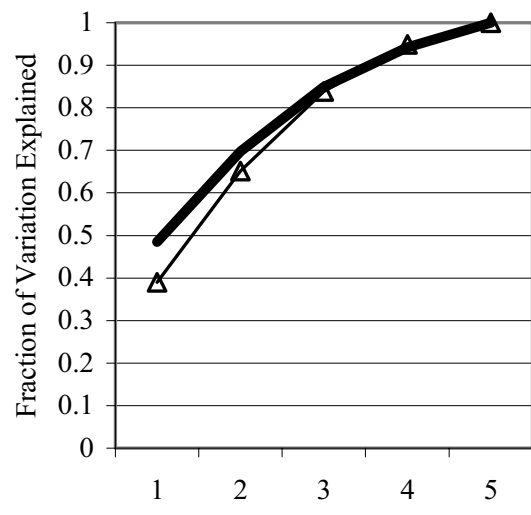

Number of Principle Components Retained $\triangle$ Pre-Crisis

Post-Crisis

\section{Latin and North America}

Europe

Fraction of the Total Variation in the Data Captured By the First $\mathrm{n}$ Principle Components; Stock Market Crash 1929

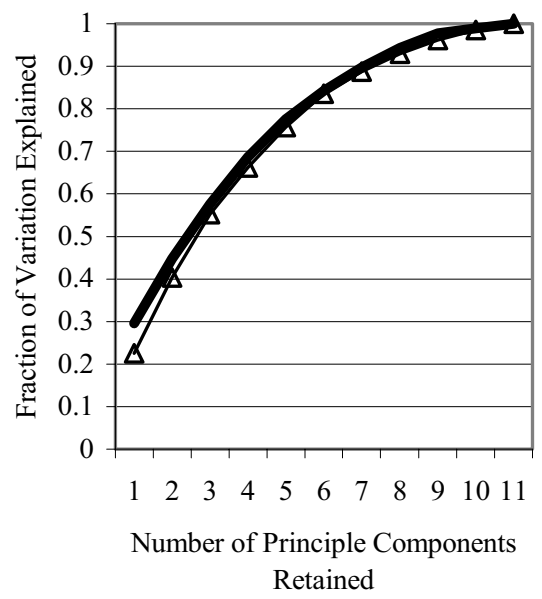

$\triangle$ Pre-Crisis

$\longrightarrow$ Post-Crisis

Europe

Fraction of the Total Variation in the Data Captured By the First n Principle Components; Sterling Devaluation, 1931

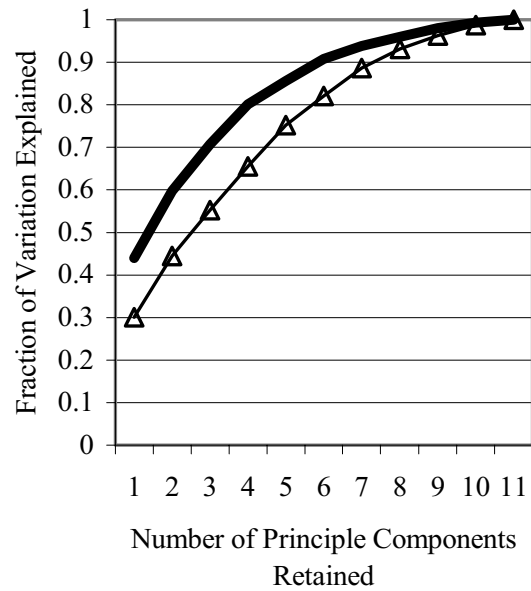

$\triangle$ Pre-Crisis

$\longrightarrow$ Post-Crisis 
Figure 4. A. Pre-Crisis and Post-Crisis Comovement in Bond Prices By Region; Interwar

Fraction of the Total Variation in the Data Captured By the First $\mathrm{n}$ Principle Components; Dollar Devaluation, 1933

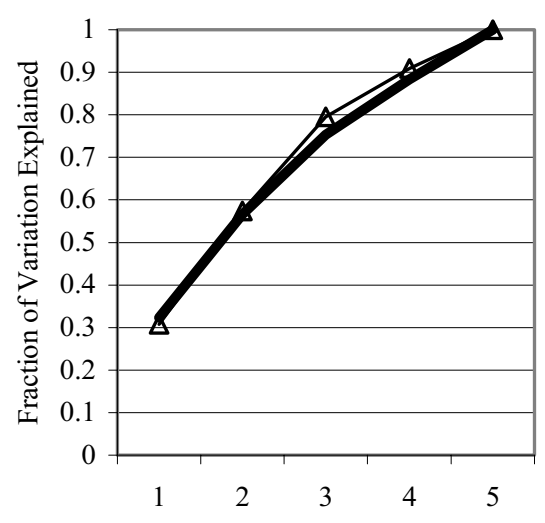

Number of Principle Components Retained

\section{$\triangle$ Pre-Crisis
Post-Crisis}

Latin and North America
Fraction of the Total Variation in the Data Captured By the First $n$ Principle Components; Dollar Devaluation, 1933

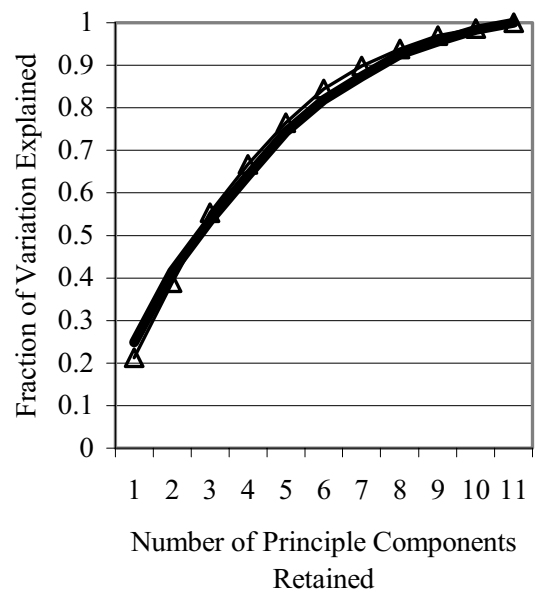

$\triangle$ Pre-Crisis

$\longrightarrow$ Post-Crisis

\section{Europe}


Fraction of the Total Variation in the Data Captured By the First $\mathrm{n}$ Principle Components; Peso Devaluation, 1994

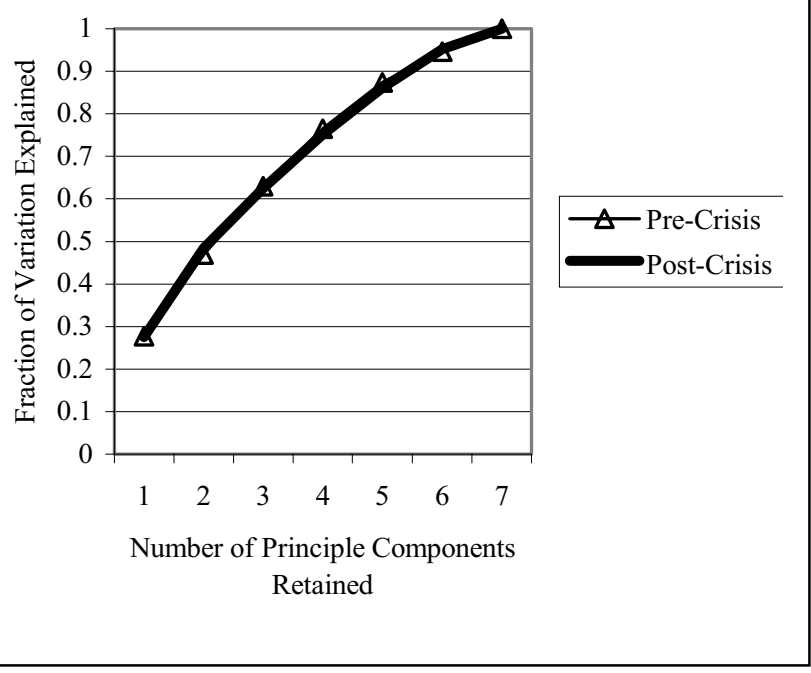

Pacific Rim

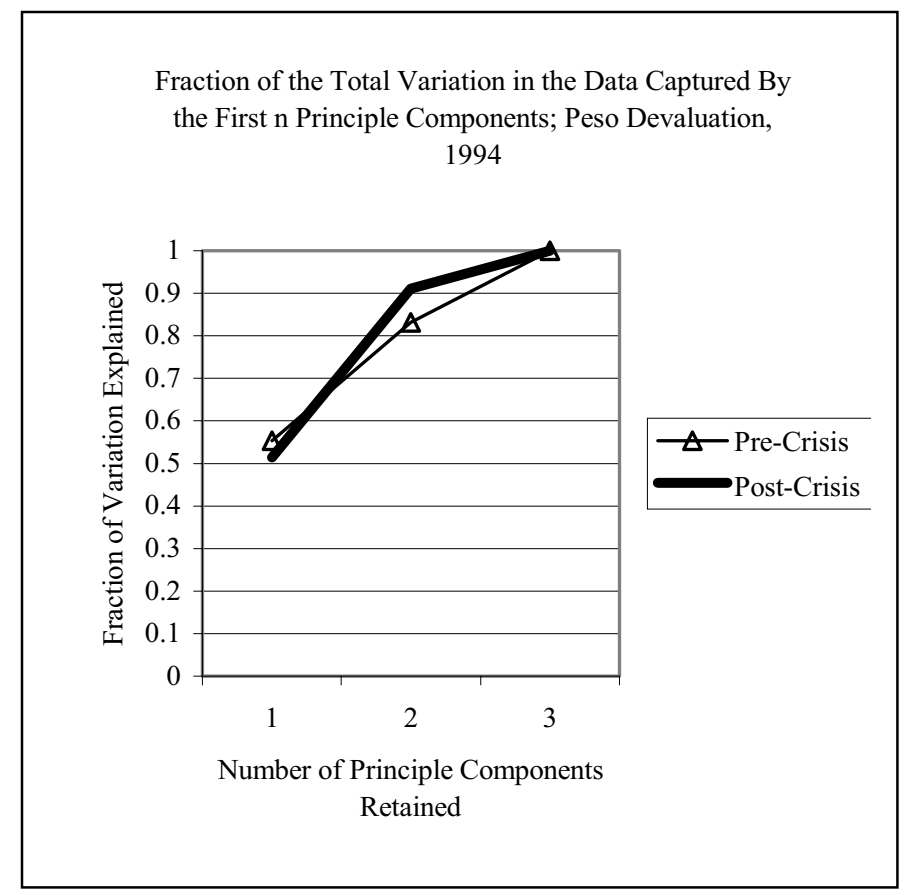

Latin and North America

Fraction of the Total Variation in the Data Captured By the First n Principle Components; Peso Devaluation, 1994

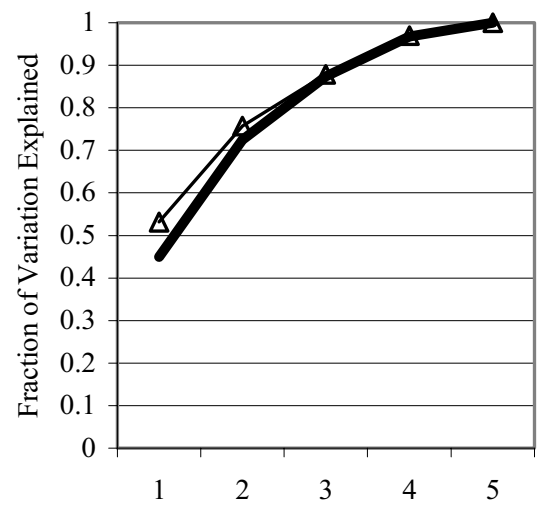

$\triangle$ Pre-Crisis

Post-Crisis

Number of Principle Components

Retained

\section{Europe}


Figure 4. B. Pre-Crisis and Post-Crisis Comovement in Bond Prices By Region; Recent Period

Fraction of the Total Variation in the Data Captured

By the First $n$ Principle Components; Thai Devaluation 1997

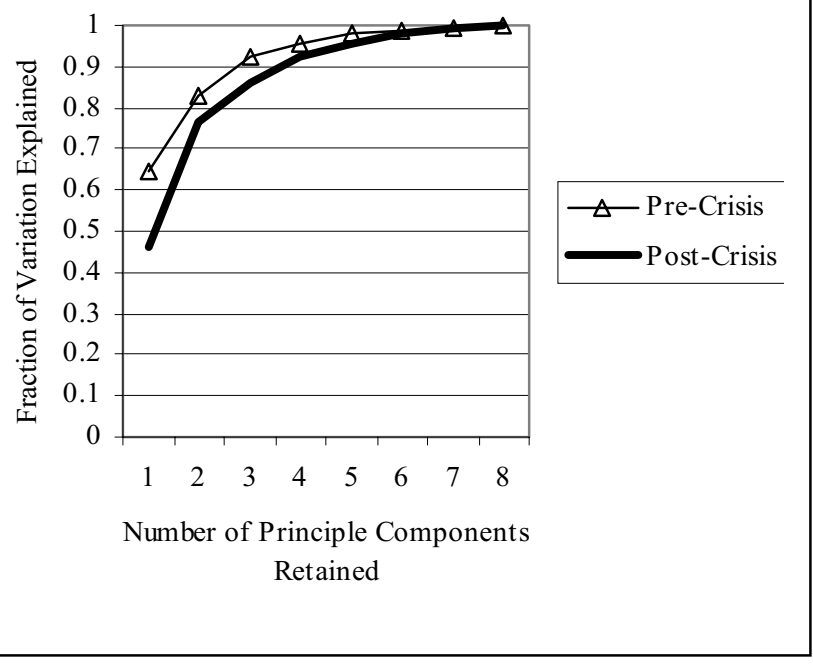

Pacific Rim

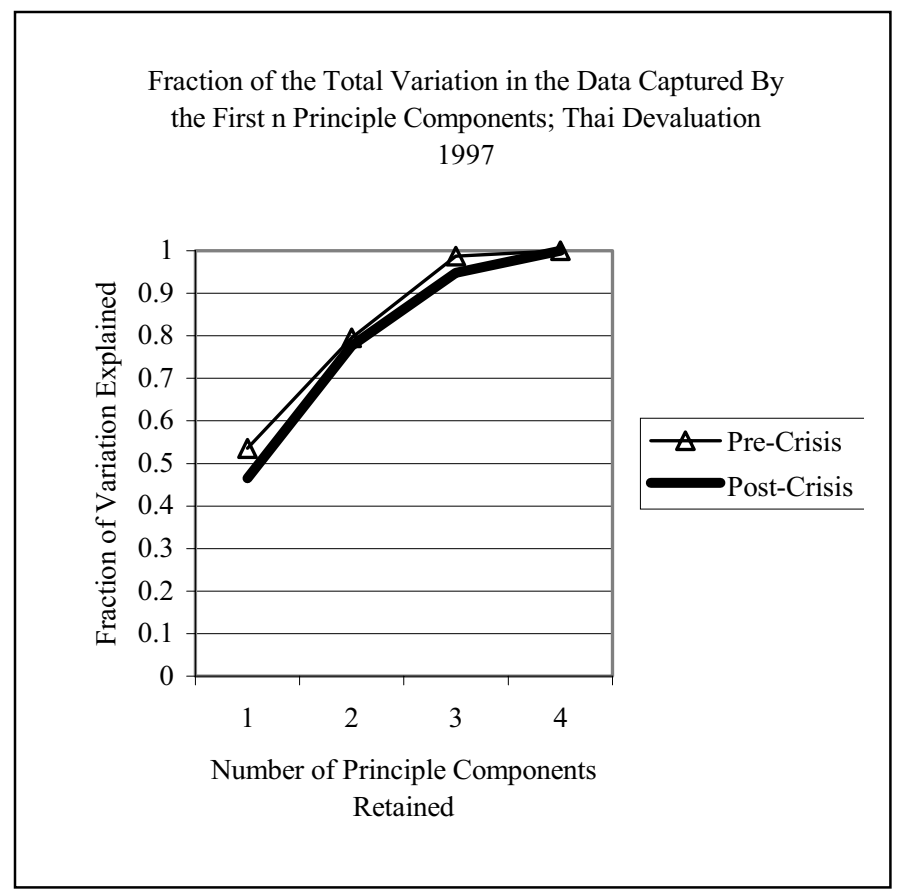

Latin and North America

Fraction of the Total Variation in the Data Captured By the First $\mathrm{n}$ Principle Components; Thai Devaluation 1997

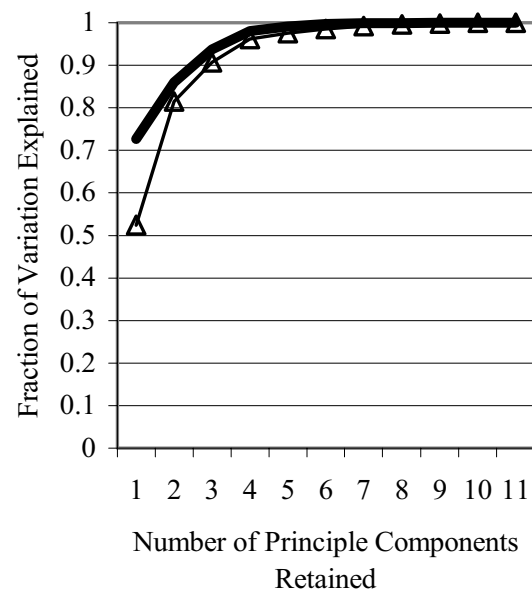

$\triangle$ Pre-Crisis

$\longrightarrow$ Post-Crisis

Retained

\section{Europe}


Fraction of the Total Variation in the Data Captured By the First n Principle Components; Stock Market Crash, 1929

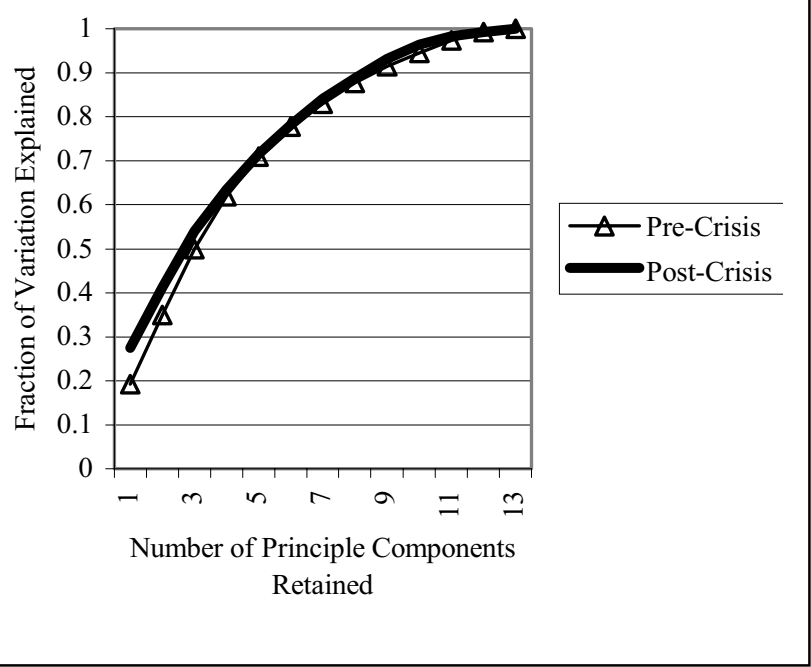

Advanced

Fraction of the Total Variation in the Data Captured By the First $\mathrm{n}$ Principle Components; Sterling Devaluation, 1931

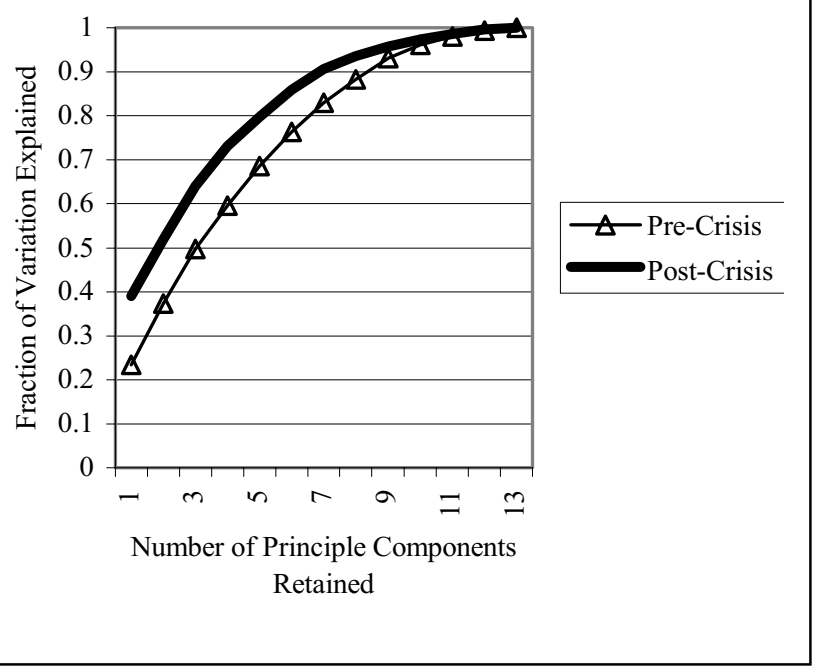

Advanced
Fraction of the Total Variation in the Data Captured By the First $n$ Principle Components; Stock Market Crash 1929

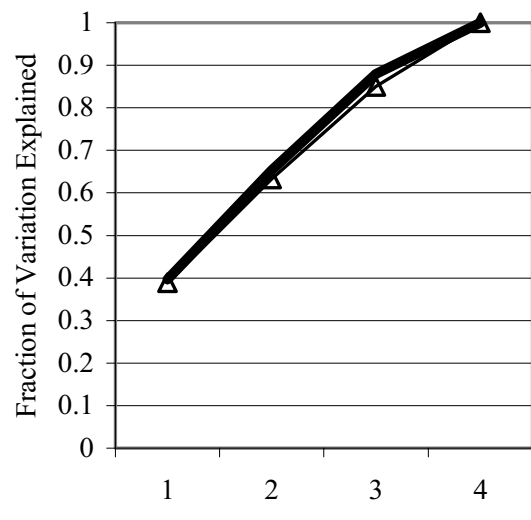

Number of Principle Components Retained

\section{Emerging}

Fraction of the Total Variation in the Data Captured By the First $\mathrm{n}$ Principle Components; Sterling Devaluation, 1931

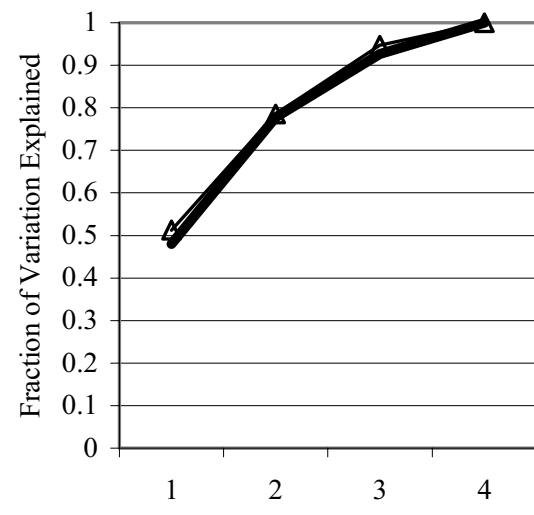

$\triangle$ Pre-Crisis

Post-Crisis

Number of Principle Components Retained

Emerging 
Figure 5. A. Pre-Crisis and Post-Crisis Comovement in Bond Prices By Advanced and Emerging

Countries; Interwar

Fraction of the Total Variation in the Data Captured By the First $n$ Principle Components; Dollar Devaluation, 1933

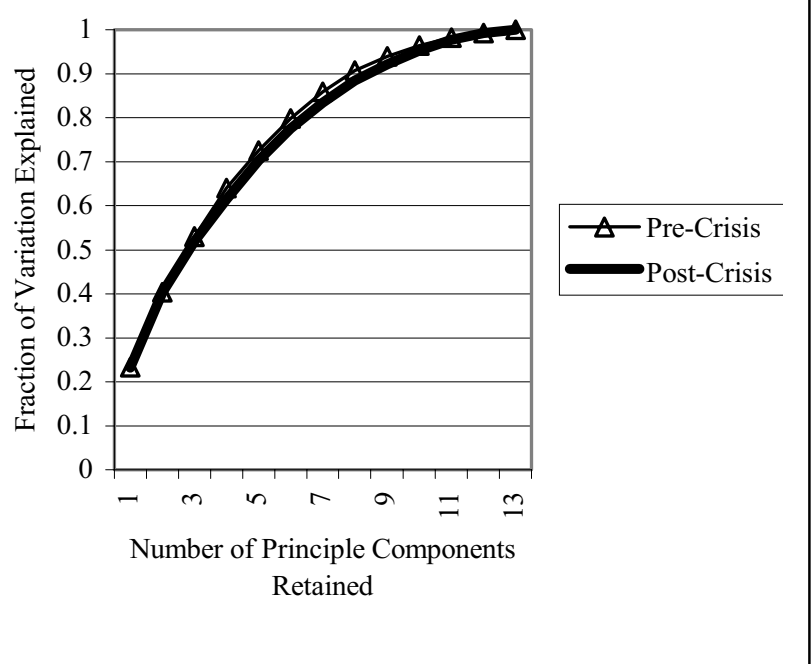

Advanced

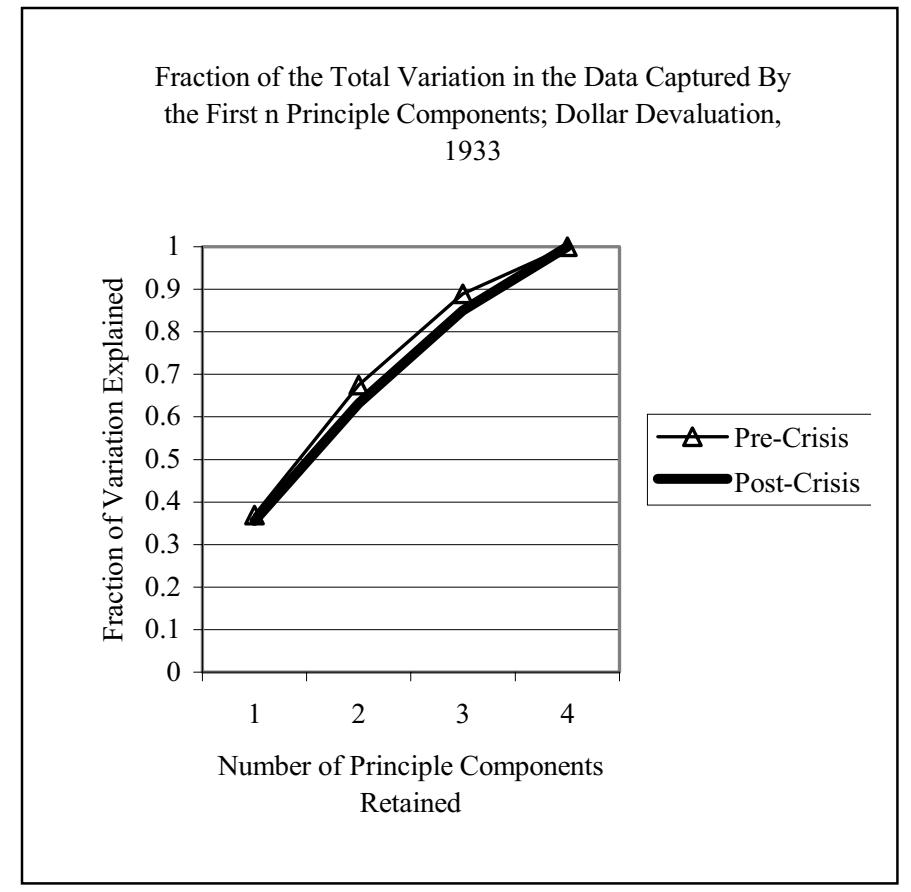

Emerging 
Fraction of the Total Variation in the Data Captured By the First $\mathrm{n}$ Principle Components; Peso Devaluation, 1994

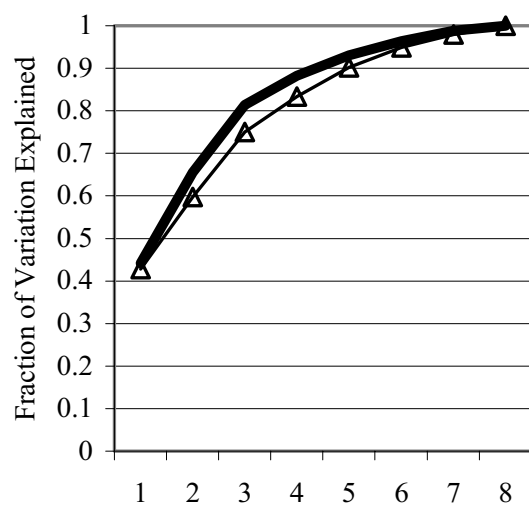

Number of Principle Components Retained

\section{$\triangle$ Pre-Crisis \\ Post-Crisis}

\section{Advanced}

Fraction of the Total Variation in the Data Captured By the First $\mathrm{n}$ Principle Components; Thai Devaluation 1997
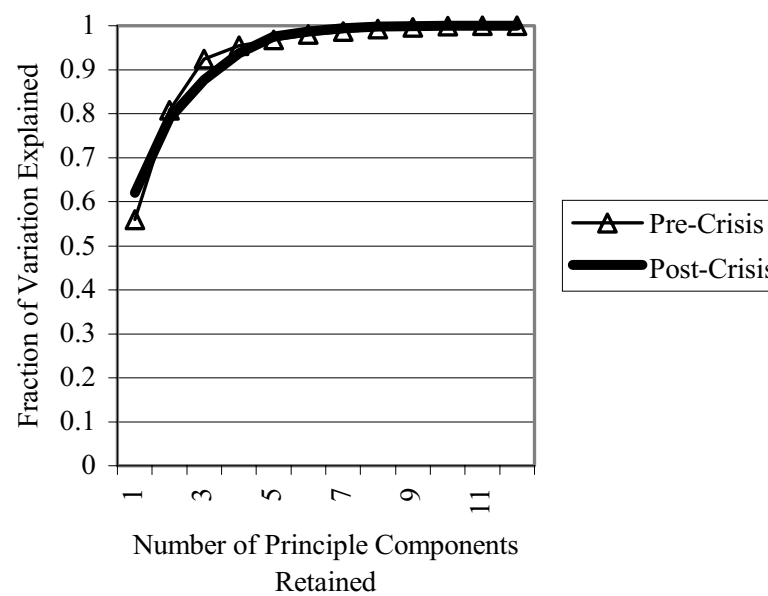

Post-Crisis

\section{Advanced}

\section{Emerging}

Fraction of the Total Variation in the Data Captured By the First $n$ Principle Components; Peso Devaluation, 1994

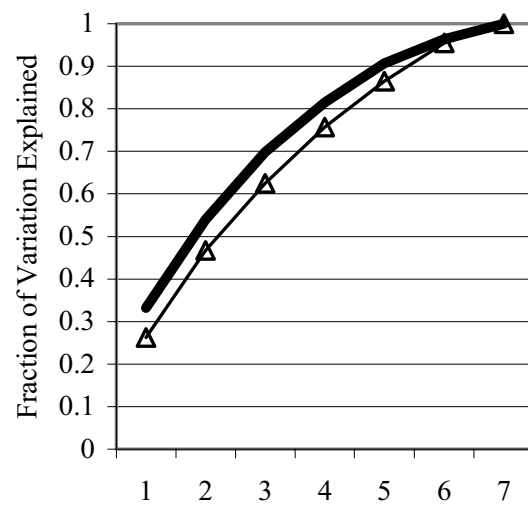

$\triangle$ Pre-Crisis

$\longrightarrow$ Post-Crisis

Number of Principle Components

Retained

\section{Emerging}

Fraction of the Total Variation in the Data Captured By the First $\mathrm{n}$ Principle Components; Thai Devaluation 1997

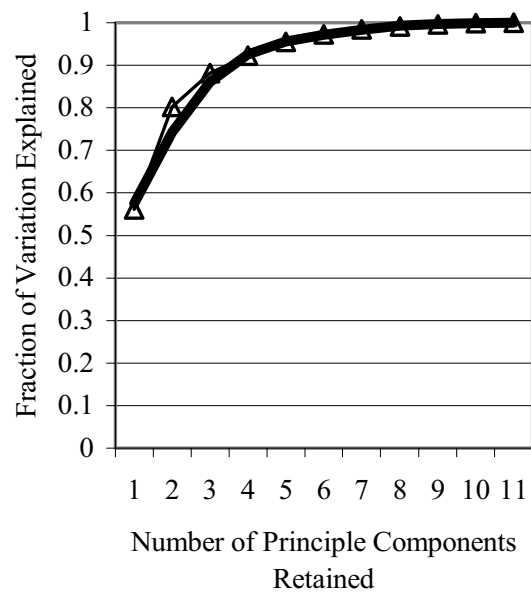

$\triangle$ Pre-Crisis

Post-Crisis 